Article

\title{
Distinct Functional Alterations and Therapeutic Options of Two Pathological De Novo Variants of the T292 Residue of GABRA1 Identified in Children with Epileptic Encephalopathy and Neurodevelopmental Disorders
}

\author{
Wenlin Chen ${ }^{1,+} \mathbb{D}$, Yang Ge ${ }^{1,+}{ }^{\text {, Jie Lu }}{ }^{1}$, Joshua Melo ${ }^{2}$, Yee Wah So ${ }^{1}$, Romi Juneja ${ }^{2, *}$, Lidong Liu ${ }^{1, * \mathbb{D}}$ \\ and Yu Tian Wang ${ }^{1}$
}

check for updates

Citation: Chen, W.; Ge, Y.; Lu, J.; Melo, J.; So, Y.W.; Juneja, R.; Liu, L.; Wang, Y.T. Distinct Functional Alterations and Therapeutic Options of Two Pathological De Novo Variants of the T292 Residue of GABRA1 Identified in Children with Epileptic Encephalopathy and Neurodevelopmental Disorders. Int. J. Mol. Sci. 2022, 23, 2723. https:// doi.org/10.3390/ijms23052723

Academic Editor: Jarogniew J. Łuszczki

Received: 31 January 2022 Accepted: 27 February 2022 Published: 1 March 2022

Publisher's Note: MDPI stays neutral with regard to jurisdictional claims in published maps and institutional affiliations.

Copyright: (C) 2022 by the authors. Licensee MDPI, Basel, Switzerland This article is an open access article distributed under the terms and conditions of the Creative Commons Attribution (CC BY) license (https:// creativecommons.org/licenses/by/ $4.0 /)$.
1 Djavad Mowafaghian Centre for Brain Health and Department of Medicine, University of British Columbia, Vancouver, BC V6T 2B5, Canada; chenwenlin1991@gmail.com (W.C.); yang.ge@ubc.ca (Y.G.); jielu@mail.ubc.ca (J.L.); evaso@mail.ubc.ca (Y.W.S.); ytwang@brain.ubc.ca (Y.T.W.)

2 Neurology Centre of Toronto, Toronto, ON M5N 1A8, Canada; joshua.melo97@gmail.com

* Correspondence: dr.romijuneja@gmail.com (R.J.); lidong@mail.ubc.ca (L.L.)

+ These authors contributed equally to this work.

\begin{abstract}
Mutations of $\mathrm{GABA}_{\mathrm{A}} \mathrm{R}$ have reportedly led to epileptic encephalopathy and neurodevelopmental disorders. We have identified a novel de novo T292S missense variant of GABRA1 from a pediatric patient with grievous global developmental delay but without obvious epileptic activity. This mutation coincidentally occurs at the same residue as that of a previously reported GABRA1 variant T292I identified from a pediatric patient with severe epilepsy. The distinct phenotypes of these two patients prompted us to compare the impacts of the two mutants on the receptor function and to search for suitable therapeutics. In this study, we used biochemical techniques and patch-clamp recordings in HEK293 cells overexpressing either wild-type or mutated rat recombinant $\mathrm{GABA}_{\mathrm{A}}$ Rs. We found that the $\alpha 1 \mathrm{~T} 292 \mathrm{~S}$ variant significantly increased GABA-evoked whole-cell currents, shifting the dose-response curve to the left without altering the maximal response. In contrast, the $\alpha 1 T 292 \mathrm{I}$ variant significantly reduced GABA-evoked currents, shifting the dose-response curve to the right with a severely diminished maximum response. Single-channel recordings further revealed that the $\alpha 1$ T292S variant increased, while the $\alpha 1$ T292I variant decreased the GABA $R$ single-channel open time and open probability. Importantly, we found that the T292S mutation-induced increase in $\mathrm{GABA}_{\mathrm{A}} \mathrm{R}$ function could be fully normalized by the negative $\mathrm{GABA}_{\mathrm{A}} \mathrm{R}$ modulator thiocolchicoside, whereas the T292I mutation-induced impairment of $\mathrm{GABA}_{\mathrm{A}} \mathrm{R}$ function was largely rescued with a combination of the $\mathrm{GABA}_{\mathrm{A}} \mathrm{R}$ positive modulators diazepam and verapamil. Our study demonstrated that $\alpha 1 \mathrm{~T} 292$ is a critical residue for controlling $\mathrm{GABA}_{\mathrm{A}} \mathrm{R}$ channel gating, and mutations at this residue may produce opposite impacts on the function of the receptors. Thus, the present work highlights the importance of functionally characterizing each individual $G_{A B A} R$ mutation for ensuring precision medicine.
\end{abstract}

Keywords: epileptic encephalopathy; neurodevelopmental disorders; de novo missense variants; GABRA1 T292 residue; channel gating properties; therapeutic options

\section{Introduction}

Epilepsy is a neurological disorder characterized by recurrent seizures that occur due to abnormally excessive electrical discharges of the cerebral neurons as a result of the disruption of the excitation-inhibition balance (E/I balance) in the brain [1-3]. About 50\% of the epilepsies diagnosed worldwide are gene-related [4]. Recent studies have identified several hundred genes associated with epilepsy, among which genes encoding ion channels/receptors predominate [3,5]. $\mathrm{As} \mathrm{a} \mathrm{Cl}^{-}$channel and the primary mediator of inhibitory 
synaptic neurotransmission in the central nervous system (CNS), the $\gamma$-aminobutyric acid $(\mathrm{GABA})$ type $\mathrm{A}$ receptor $\left(\mathrm{GABA}_{\mathrm{A}} \mathrm{R}\right)$ plays a critical role in maintaining the neuronal $\mathrm{E} / \mathrm{I}$ balance in the CNS and is considered an important genetic risk factor for epilepsy. In addition, the dysfunction of the receptor underlies the pathogenesis of many neurological diseases. Accumulating evidence suggests that genetic variants of the $\mathrm{GABA}_{\mathrm{A}} \mathrm{R}$ may cause conditions including epileptic encephalopathy (EE) [6-9], developmental delay [9,10], Fragile X, Rett Syndrome, and Dravet Syndrome [11-13].

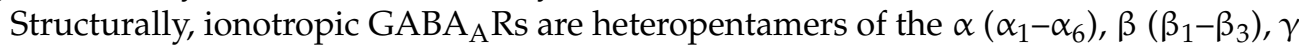
$\left(\gamma_{1}-\gamma_{3}\right), \delta, \varepsilon, \theta, \pi$, or $\rho$ subunits, with $\alpha$ and $\beta$ being the obligatory subunits [9]. Most synaptic GABA $\mathrm{A}_{\mathrm{A}}$ Rs are assembled from two $\alpha_{1}$ subunits, two $\beta_{2}$ subunits, and one $\gamma_{2}$ subunit [14]. Each subunit contains a large extracellular N-terminal domain, four transmembrane helices, two intracellular loops, and one extracellular C-terminal domain (Figure 1A) [15-17]. The receptor's agonist, GABA, binds to the agonist-binding site interfacing the extracellular N-terminal domains of the $\alpha$ and $\beta$ subunits (Figure 1B). The agonist binding triggers the conformational opening of the receptor channel and leads to chloride anion influx through the ion pore formed by the transmembrane segments of all five subunits $[13,17,18]$. Due to the pentameric composition of the $\mathrm{GABA}_{\mathrm{A}} \mathrm{R}$, mutations of the amino acid residues in many different $\mathrm{GABA}_{\mathrm{A}} \mathrm{R}$ subunits have been reported to alter the function, expression level, and subcellular distributions of the receptor [19-22].

The $\alpha 1$ subunit of the $\mathrm{GABA}_{A} R$, which is encoded by the GABRA1 gene, is ubiquitously expressed in CNS neurons, suggesting its importance in maintaining the normal function of the vast majority of native $\mathrm{GABA}_{\mathrm{A}} \mathrm{Rs}$ [23]. Indeed, increasing numbers of GABRA1 variants have been implicated in causing haploinsufficiency and loss of function of the $\mathrm{GABA}_{\mathrm{A}}$ Rs, thereby causally contributing to the pathogenesis of various forms of epilepsy [24-28], Dravet Syndrome, early-onset EEs, and developmental delay [13,29]. In nearly all patients with pathogenic GABRA1 variants, the clinical phenotypes include epilepsies within a spectrum of different severity, ranging from generalized epilepsies to severe epileptic encephalopathies [23].

We have recently identified a novel de novo T292S (C875G) missense variant of GABRA1 from a pediatric patient with developmental delay, but, to our surprise, without diagnosed seizure events. Most interestingly, this mutation occurs on the same residue as that of the previously reported variant T292I (C875T) identified from a pediatric patient with severe epilepsy [19]. The dramatic difference between the phenotypes of the two patients and the resistance to the standard care treatments of the patient harbouring the T292S mutation prompted us to characterize and compare the pathological impacts of the two mutations on the function of the $G_{A B A} R$ and potentially search for the most suitable and effective pharm-therapeutics. To accomplish our goals, we used surface biotinylation, Western blotting, and whole-cell and single-channel patch-clamp recordings to characterize the two variants in HEK293 cells overexpressing either the wild-type or mutant rat recombinant $\mathrm{GABA}_{\mathrm{A}}$ Rs containing the $\alpha 1 / \beta 2 / \gamma 2$ subunits. We found that the two mutations have drastically different impacts on the receptor function: The $\alpha 1_{\mathrm{T} 292 \mathrm{~S}}$ variant significantly increased, whereas the $\alpha 1_{\text {T292I }}$ variant significantly reduced $G_{A B A} R$ function. The opposite functional impacts of these mutations suggest that we would need different therapeutic strategies for treating the patients carrying these mutations. Indeed, through screening several clinically approved drugs that reportedly act on $\mathrm{GABA}_{\mathrm{A}} \mathrm{Rs}$, we found that the $\mathrm{GABA}_{\mathrm{A}} \mathrm{R}$ allosteric inhibitor thiocolchicoside (TCC) [30] could reduce the gain of function caused by the T292S mutation, thereby normalizing the receptor function. On the other hand, a combination of $\mathrm{GABA}_{\mathrm{A}} \mathrm{R}$ positive modulators, diazepam and verapamil [18,20], largely rescued the loss of function caused by the T292I mutation. Our results, particularly the gain of function caused by $\alpha 1_{\mathrm{T} 292 \mathrm{~S}}$, are in great contrast to the loss of function of most, if not all, previously reported pathogenic GABRA1 mutations [19]. This highlights the importance of the functional characterization of and search for different therapeutic strategies for each individual mutation. 

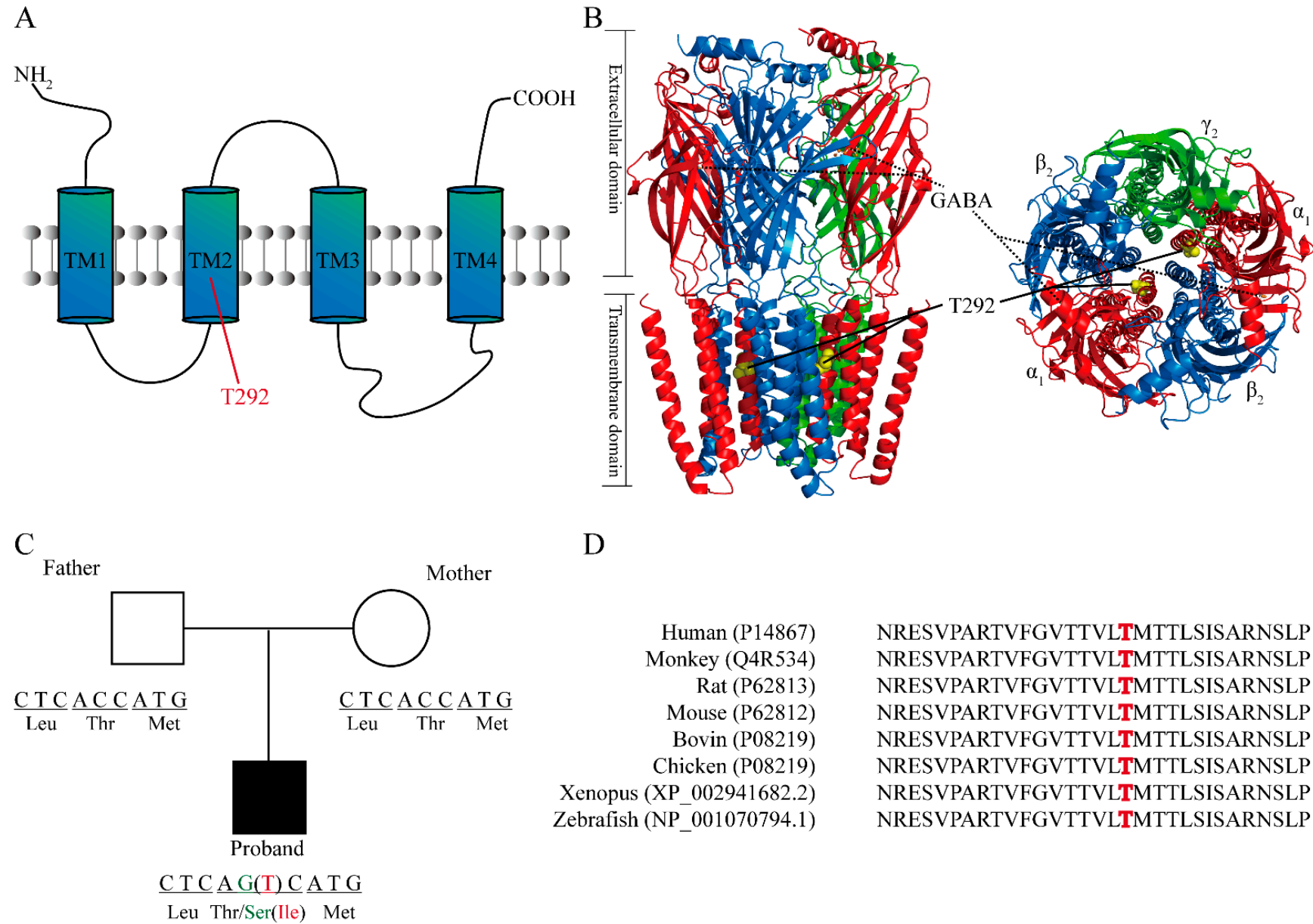

$\mathrm{D}$
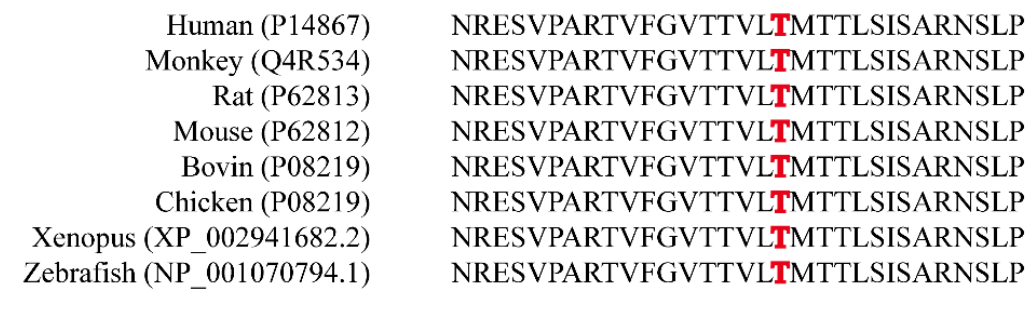

Leu $\mathrm{Thr} / \mathrm{Ser}(\mathrm{Ile})$ Met

Figure 1. Structural analysis and the location of the T292 residue in GABRA1 and depiction of the de novo missense variants $c .875 C>G$ (p.Thr292Ser) (green) and $c .875 C>T$ (p.Thr292Ile) (red). (A) Diagram represents the T292 residue located at GABRA1 TM2. (B) Cryo-EM structure of the $\mathrm{GABA}_{\mathrm{A}}$ receptor (PDB ID 6X3U) with highlighted T292 residue (yellow) and the bond agonist GABA (orange). As indicated, the T292 residue forms part of the inner channel pore. (C) Depiction of the two de novo missense variants in the patients and unaffected parents. (D) Comparison of the GABRA1 protein from several species indicates that Thr292 (in bold red) and nearby amino acids are evolutionarily conserved. Protein sequences were acquired from Uniprot and Ensembl.

\section{Results}

\subsection{Phenotypic Comparisons of the Two Patients Carrying the GABRA1 Mutants}

Our patient was a 2-year-old boy with severe neurodevelopmental delays manifested as visual impairment, feeding difficulties, and significantly below-average body weight and organ mass. He had, however, no diagnosed overt seizure activity despite a few abnormal electroencephalography (EEG) discharges observed. In addition, there was no abnormality that could be found in MRI. No similar neurodevelopmental phenotype has been observed in his siblings or family members. Through whole-exome sequencing (WES), we identified a novel de novo T292S (C875G) missense variant of GABRA1. The clinical phenotypes, particularly the lack of any observable somatic seizure activity, are drastically different from that of a previously reported patient who carried a de novo variant at the same residue T292I (C875T) and had the main clinical features of Lennox-Gastaut syndrome with light-sensitive myoclonic epilepsy, generalized tonic-clonic seizures, and developmental delay $[19,31]$. These strikingly different clinical phenotypes may implicate distinct impacts on the receptor functions by these two mutations albeit occurring on the same residue. 


\subsection{Structural Analysis and the Location of T292 Residue in GABRA1}

The $\alpha 1$. T292 residue is located in the second transmembrane domain (TM2) of the $\alpha_{1}$ subunit (Figure 1A) and lies within the inner channel pore (Figure 1B). The parents of both patients have normal alleles, but the patients have the heterozygous missense variant of the same site in GABRA1 (NM_000806.5: C.875C > G or 875C > T, NP_000797.2: p.Thr292Ser or Thr292Ile; Figure 1C). Sequence alignment demonstrates that this residue is highly conserved among different species, including human, monkey, rat, mouse, bovine, chicken, xenopus, and zebrafish species, implying the importance of this residue (Figure 1D). This is in good agreement with previous studies reporting that modification or pathogenic variant of the channel-lining residues could lead to dramatic alterations of the receptor function, particularly channel-gating properties [32,33].

\subsection{The T292S and T292I Variants Bidirectionally Affect GABA-Evoked Responses}

The drastic differences in the clinical phenotypes of the two mutations may imply significantly different impacts on the $\mathrm{GABA}_{\mathrm{A}} \mathrm{R}$ function. Since the functional impacts of neither variant have previously been fully characterized, we employed whole-cell patchclamp recordings of GABA-evoked currents to test whether the variants would affect $\mathrm{GABA}_{\mathrm{A}} \mathrm{R}$ functions. The evoked whole-cell currents were measured by fast perfusion $(2 \mathrm{~s})$ of GABA with concentrations ranging from $0.1 \mu \mathrm{M}$ to $1 \mathrm{mM}$ at a holding membrane potential of $-60 \mathrm{mV}$ in HEK293 cells transiently overexpressing wild-type $\alpha 1 / \beta 2 / \gamma 2$, $\alpha 1_{\mathrm{T} 292 \mathrm{~S}} / \beta 2 / \gamma 2$, or $\alpha 1_{\mathrm{T} 292 \mathrm{I}} / \beta 2 / \gamma 2$.

For the wild-type $\mathrm{GABA}_{\mathrm{A}}$ Rs, GABA-evoked inward currents increased in a dosedependent manner, in which the currents were observable at $1 \mu \mathrm{M}$ and reached the maximum level at around $100 \mu \mathrm{M}$. In comparison with the wild-type receptor, the GABA sensitivity of the $\alpha 1_{\mathrm{T} 292 \mathrm{~S}} \mathrm{GABA}_{\mathrm{A}}$ Rs was significantly increased (Figure 2). The currents gated by the mutated receptor were observable at the concentration of $0.1 \mu \mathrm{M}$ of GABA and reached the maximal at around $10 \mu \mathrm{M}$ of GABA (Figure 2A). When we normalized the currents to the cell's own maximum response, we found that in comparison with the wild-type $\mathrm{GABA}_{\mathrm{A}}$ Rs, T292S GABA $\mathrm{A}_{\mathrm{A}}$ Rs had shifted its dose-response curve to the left (Figure 2C) and lowered its EC50 by more than ten-fold (T292S: $0.2895 \mu \mathrm{M}$; WT: $3.658 \mu \mathrm{M}$ ) (Figure 2C,E). However, when we normalized the currents of the T292S GABA $\mathrm{As}(3287 \pm 422.5 \mathrm{pA})$ against the maximum response of WT $(3075 \pm 526.0 \mathrm{pA})$, we observed that the maximum response of the T292S GABA ${ }_{A}$ Rs was not affected (Figure 2B,D). To mimic the patient's heterozygous expression of the mutant subunit, we co-transfected both the wild-type $\alpha 1_{\mathrm{T} 292}$ and the $\alpha 1_{\mathrm{T} 292 \mathrm{~S}}$ mutant in a 1:1 ratio along with the $\beta 2$ and $\gamma 2$ subunits in HEK293 cells. We found that this heterozygous expression caused a shift of the GABA-evoked dose-response curve toward the midpoint between the wild-type and the homozygous curves (Supplemental Figure S1).

In stark contrast, the expression of the T292I mutant resulted in significant impairment of $\mathrm{GABA}_{\mathrm{A}} \mathrm{R}$ function. It severely reduced the peak current amplitude at each concentration tested (Figure 2A) with a drastically decreased maximum response $(1033 \pm 286.5 \mathrm{pA}$, which was only about one-third of the response of the wild-type or T292S GABA $A_{A} R s$ ) (Figure 2B,D). The reduced maximum response was also associated with a rightwardshifted dose-response curve and a more than 18-fold increased EC50 over the wild-type GABA $_{\mathrm{A}}$ R (T292I: $69.28 \mu \mathrm{M}$; WT: $3.658 \mu \mathrm{M}$ ) (Figure 2C-E).

To check whether either of the two variants could affect the ion selectivity of $G_{A B A} R$, chloride ion channel amplitudes of the GABA-evoked peak currents were measured at stepwise membrane potentials ranging from -80 to $+80 \mathrm{mV}$ with $20 \mathrm{mV}$ intervals. As shown in Figure 2F,G, we found that neither variant compromised the ion selectivity since the reversal potentials of both variant receptors were similar to that of wild-type receptors, in which all were at approximately $0 \mathrm{mV}$. 
A

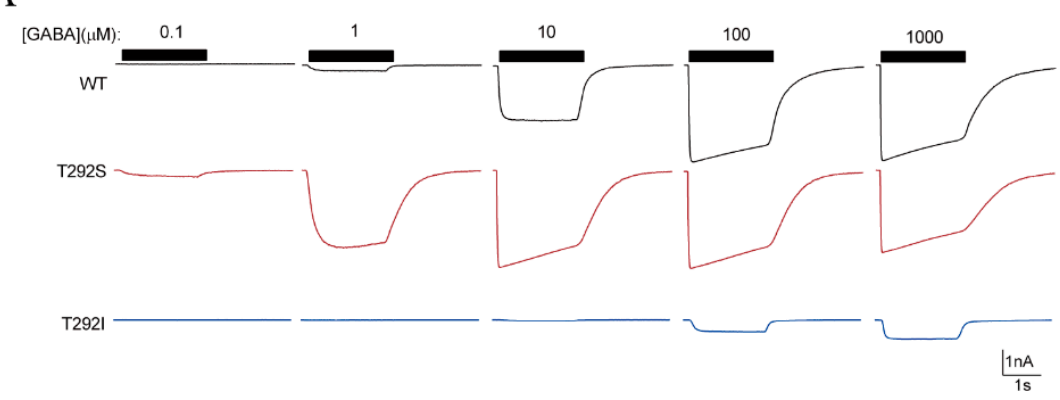

$\mathrm{C}$

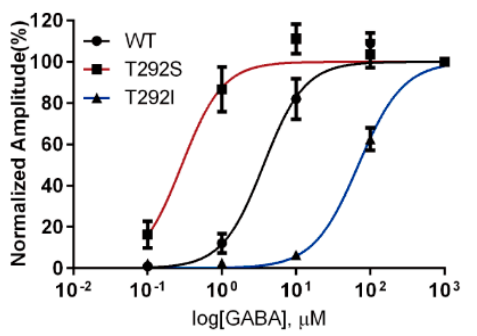

$\mathrm{F}$

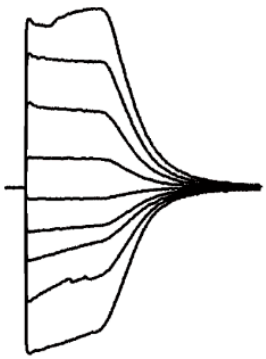

$\mathrm{D}$
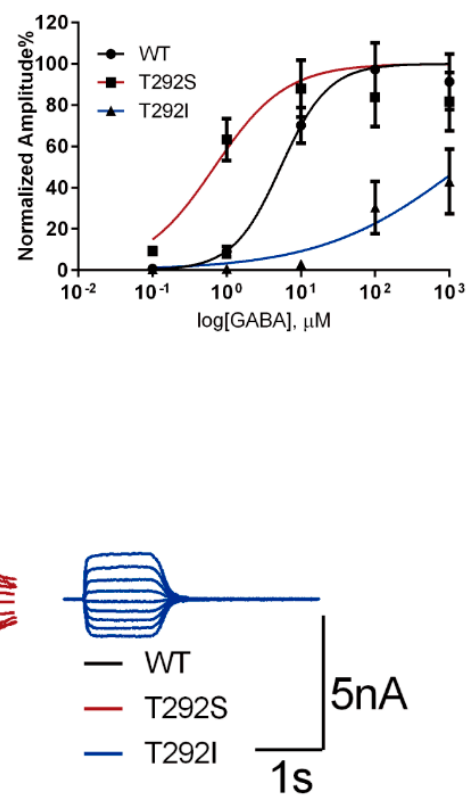

$\mathrm{B}$

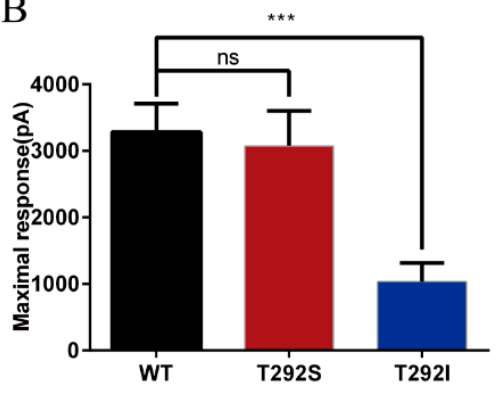

$\mathrm{E}$

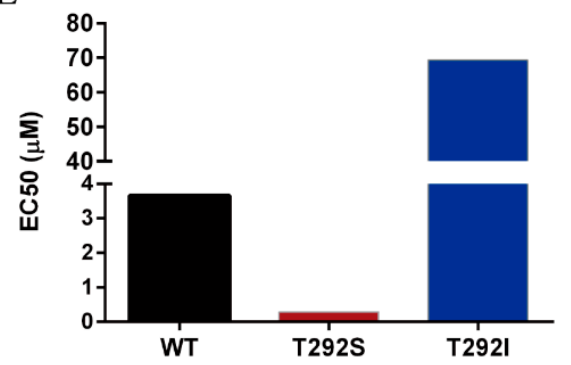

G

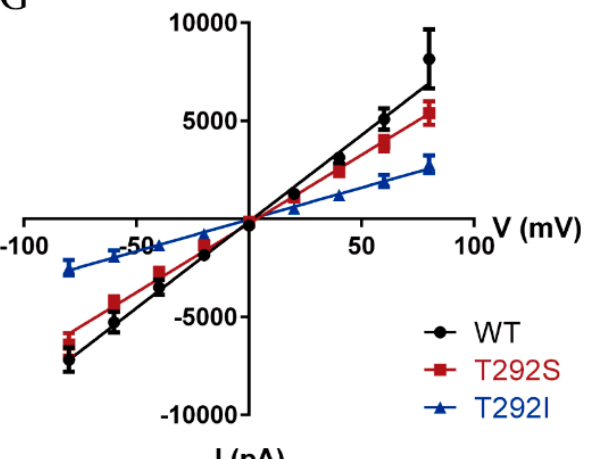

Figure 2. GABA-evoked responses of WT (black), $\alpha 1_{\mathrm{T} 292 \mathrm{~S}}$ (red), and $\alpha 1_{\mathrm{T} 292 \mathrm{I}}$ (blue) of $\mathrm{GABA}_{\mathrm{A}} \mathrm{R}$ show bidirectional changes in two de novo mutations at the same T292 residue of GABRA1. (A) Representative traces of GABA-evoked currents of $\mathrm{WT}, \alpha 1_{\mathrm{T} 292 \mathrm{~S}}$, and $\alpha 1_{\mathrm{T} 292 \mathrm{I}}$ of $\mathrm{GABA}_{\mathrm{A}} \mathrm{R}$. GABA application (2 s) is indicated as a bold black line above the traces. (B) Maximum response of $\alpha 1_{\mathrm{T} 292 \mathrm{~S}}$ $(n=10)$ and $\alpha 1_{\mathrm{T} 292 \mathrm{I}}(n=12)$ of $\mathrm{GABA}_{\mathrm{A}} \mathrm{R}$ in comparison with WT $(n=8)$. (C) Dose-response curves of GABA-evoked responses of WT $(n=8), \alpha 1_{\mathrm{T} 292 \mathrm{~S}}(n=10)$, and $\alpha 1_{\mathrm{T} 292 \mathrm{I}}(n=12)$ of $\mathrm{GABA}_{\mathrm{A}} \mathrm{R}$. The peak current amplitude at each GABA concentration was normalized to the maximum response $(1 \mathrm{mM})$ of each receptor, respectively. (D) Dose-response curves of GABA-evoked responses of WT ( $n=8)$, $\alpha 1_{\mathrm{T} 292 \mathrm{~S}}(n=10)$, and $\alpha 1_{\mathrm{T} 292 \mathrm{I}}(n=12)$ of $\mathrm{GABA}_{\mathrm{A}} \mathrm{R}$. The peak current amplitude at each GABA concentration was normalized to the maximum response (1 mM) of WT. (E) EC50 of GABA-evoked response of WT, $\alpha 1_{\mathrm{T} 292 \mathrm{~S}}$, and $\alpha 1_{\mathrm{T} 292 \mathrm{I}} \mathrm{GABA}_{\mathrm{A}} \mathrm{R}$. (F) Representative trace of I-V curve. (G) I-V curves for WT $(n=5)$ and mutant $(n=5) \mathrm{GABA}_{\mathrm{A}} \mathrm{R}$-gated currents evoked by $1 \mathrm{mM}$ GABA. Statistical differences were determined using Student's $t$-test ${ }^{* * *} p<0.001, \mathrm{~ns}=$ not significant).

\subsection{Neither T292S nor T292I Variants Affected GABA $R$ R Total/Surface Expressions}

The marked functional alterations of the two variants in the GABA-evoked currents were quite intriguing and prompted us to probe the mechanisms underlying the bidirectional changes. Functional changes could be due to changes in receptor expression

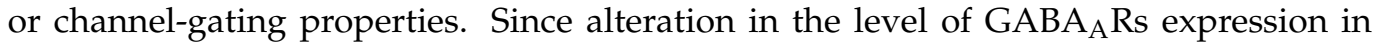
the cell and/or on the cell membrane, including other previously identified $\mathrm{GABA}_{\mathrm{A}} \mathrm{R}$ variants $[23,34,35]$, have previously been reported to be important methods of regulating the functions of the receptors with physiological and pathogenic consequences, we first 
examined the possibility that these two variants would exert their impacts on the receptor by affecting the receptor total and/or surface expression levels. We quantified the total receptors expressed in the cell by immunoblotting total cell lysates and quantified the surface receptors expressed on the plasma membrane by specifically immunoblotting biotinylated surface receptors (Figure 3 ) in HEK cells transiently expressing wild-type $\alpha 1 / \beta 2 / \gamma 2, \alpha 1_{\mathrm{T} 292 \mathrm{~S}} / \beta 2 / \gamma 2$, or $\alpha 1_{\mathrm{T} 292 \mathrm{I}} / \beta 2 / \gamma 2$. To our surprise, unlike other previously identified $\mathrm{GABA}_{\mathrm{A}} \mathrm{R}$ variants $[19,20,22]$, we found that in comparison with the WT receptors, neither variant produced any significant alteration in either the total or the surface expression levels of the receptor (Figure 3A-D).
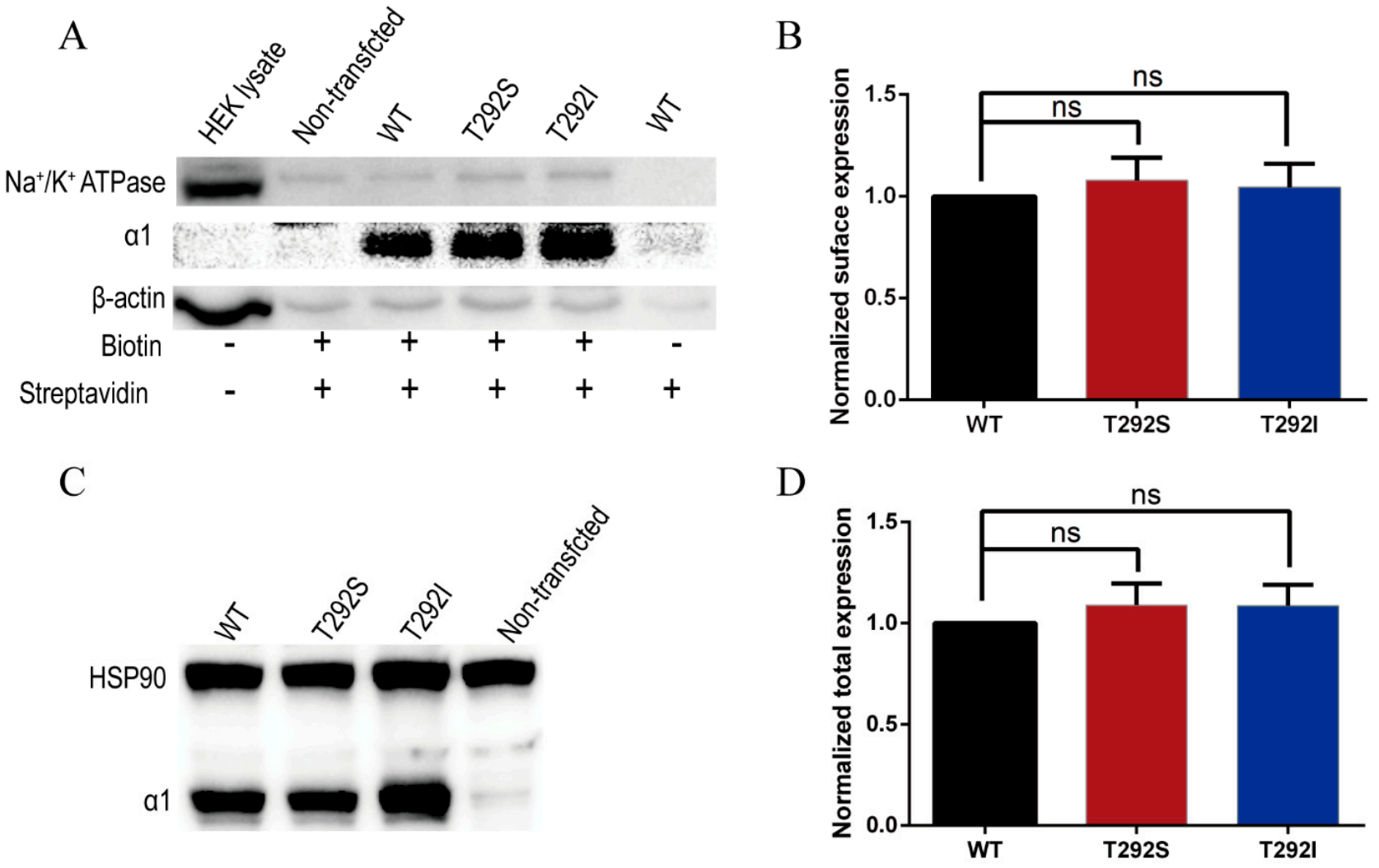

Figure 3. T292S and T292I variants did not affect $\mathrm{GABA}_{\mathrm{A}} \mathrm{R}$ total/surface expressions. (A) Representative blots of surface biotinylation of $\mathrm{WT}, \alpha 1_{\mathrm{T} 292 \mathrm{~S}}$, and $\alpha 1_{\mathrm{T} 292 \mathrm{I}}$ of $\mathrm{GABA}_{\mathrm{A}} \mathrm{R}$ and non-transfected HEK293. (B) Quantification of the surface $\alpha 1$ subunit expression normalized to $\mathrm{Na}^{+} / \mathrm{K}^{+}$ATPase $(n=9)$. (C) Representative blots of the total expression levels from $\mathrm{WT}, \alpha 1_{\mathrm{T} 292 \mathrm{~S}}$, and $\alpha 1_{\mathrm{T} 292 \mathrm{I}}$ of GABA $_{\mathrm{A}} \mathrm{R}$ and non-transfected HEK293 samples. (D) Quantification of the total $\alpha 1$ subunit expression normalized to heat shock protein 90 (HSP90) $(n=7)$. Statistical differences were determined using one-way ANOVA (ns = not significant).

\subsection{T292S and T292I Variants Bidirectionally Altered $G A B A_{A} R$ Single Channel Properties}

Since neither T292S nor T292I mutation affected GABA $A_{A} R$ expression in the cell or on the plasma membrane as shown above, we next examined the possibility that the functional alterations resulted from the changes in channel-gating properties. We employed cellattached, single-channel recordings of the WT and mutant $\mathrm{GABA}_{\mathrm{A}}$ Rs transiently expressed in HEK cells with subsaturating $(3 \mu \mathrm{M})$ or saturating $(1 \mathrm{mM})$ concentrations of GABA contained in the recording pipette. As shown in Figure 4A-E, we found that the T292S mutant significantly increased GABA-evoked single-channel activity at subsaturating, but not at saturating, GABA concentrations. When induced by $3 \mu \mathrm{M}$ of GABA, the T292S variant significantly increased the mean open time (T292S: $31.22 \pm 3.532 \mathrm{~ms}$ vs. WT: $16.58 \pm 0.4146 \mathrm{~ms}$ ), and hence the open probability (T292S: $23.58 \pm 4.279 \%$ vs. WT: $8.528 \pm 1.34 \%$ ) of $\mathrm{GABA}_{\mathrm{A}} \mathrm{R}$ 
without changing the channel conductance (T292S: $29.16 \pm 1.492$ pS, WT: $29.51 \pm 1.806$ pS) and channel open frequency (T292S: $7.982 \pm 1.719 \mathrm{~s}^{-1}$, WT: $5.172 \pm 0.8122 \mathrm{~s}^{-1}$ ) in comparison with the WT GABA $\mathrm{R}$ (Figure 4A-E), which was in good agreement with the increased sensitivity to GABA. In contrast, the T292I mutant significantly reduced sensitivity to GABA in comparison with the WT receptors as no detectable single-channel event under subsaturating concentrations of GABA (Figure 4A-E) was observed. When the currents were evoked with GABA at a concentration of $1 \mathrm{mM}$, the T292S GABA $\mathrm{A}_{\mathrm{A}}$ showed no significant alterations of conductance (T292S: $28.27 \pm 2.199 \mathrm{pS}$ vs. WT: $24.76 \pm 1.095 \mathrm{pS}$ ), mean open time (T292S: $33.77 \pm 5.447 \mathrm{~ms}$ vs. WT: $30.36 \pm 4.247 \mathrm{~ms}$ ), open frequency (T292S: $10.7 \pm 2.358 \mathrm{~s}^{-1}$ vs. WT: $8.403 \pm 2.057 \mathrm{~s}^{-1}$ ), or open probability (T292S: $30.19 \pm 4.249 \%$ vs. WT: $22.93 \pm 5.094 \%$ ) (Figure 4F-J), which was in good agreement with the no observed change in the maximum response in the whole-cell current recordings mentioned above. (Figure 2). As expected, the T292I variant significantly reduced the single-channel activity evoked by the high concentration of GABA $(1 \mathrm{mM})$. In particular, while no change in the conductance (T292I: $24.71 \pm 1.396 \mathrm{pS}$, WT: $24.76 \pm 1.095 \mathrm{pS}$ ) could be detected, both the channel-opening frequency (T292I: $4.806 \pm 1.234 \mathrm{~s}^{-1}$, WT: $8.403 \pm 2.057 \mathrm{~s}^{-1}$ ) and open probability (T292S: $7.502 \pm 2.224 \%$, WT: $22.93 \pm 5.094 \%$ ) were significantly reduced, leading to a reduced mean open time (T292I: $15.41 \pm 2.251 \mathrm{~ms}$, WT: $30.36 \pm 4.247 \mathrm{~ms}$ ) when compared with the recordings from the WT counterparts (Figure $4 \mathrm{~F}-\mathrm{J}$ ). The results imply that the impaired function of the $\mathrm{GABA}_{\mathrm{A}}$ Rs by the T292I mutation can be attributed to the decreased open probability and opening frequency of the channel.

\subsection{T292S and T292I Variants Resulted in Different Changes of $G A B A_{A} R$-Gated Tonic and Leak Currents}

We noticed in a recent study by Butler, K.M., et al. that a T292K variant of the $\alpha_{2}$ subunit caused the tonic opening of $\mathrm{GABA}_{\mathrm{A}}$ Rs [22]. Since the $\alpha_{1}$ and $\alpha_{2}$ subunits are highly homologous, we wondered whether the T292S and T292I variants in the $\alpha 1$ subunit would cause any changes to the tonic/leak currents of $\mathrm{GABA}_{\mathrm{A}}$ Rs. The GABA tonic current is the current gated through the $\mathrm{GABA}_{\mathrm{A}} \mathrm{R}$ that is activated by the ambient GABA in the extracellular solution, and it can be revealed by blocking the $\mathrm{GABA}_{\mathrm{A}} \mathrm{R}$ with the competitive antagonist bicuculline [36]. The leak current is the current gated through the channel pore of the non-activated $\mathrm{GABA}_{\mathrm{A}} \mathrm{R}$ and is usually revealed with a receptor channel pore blocker, such as picrotoxin [37]. We found that $20 \mu \mathrm{M}$ of bicuculline was already enough to block all tonic current because the application of a higher concentration $(50 \mu \mathrm{M})$ did not induce a further blockade (Supplemental Figure S2A,B). Bath application of the saturated bicuculline $(20 \mu \mathrm{M})$ produced pronounced tonic currents as evident by the upward baseline current drifting in cells expressing T292S GABA $\mathrm{A}_{\mathrm{A}}(249 \pm 52.6 \mathrm{pA})$. In great contrast, bicuculline application resulted in only minimal or no tonic currents in cells expressing either the WT $(13.63 \pm 5.641 \mathrm{pA})$ or T292I $(0.3709 \pm 0.8945 \mathrm{pA})$ receptors (Figure 5A,B). Similarly, bath application of picrotoxin $(100 \mu \mathrm{M})$ revealed a notable leak current as evident with a small additional increase upward current on top of the bicuculline-induced tonic currents only in cells expressing the T292S GABA $\mathrm{A}_{\mathrm{A}}$ Rs $(72.22 \pm 16.44 \mathrm{pA})$, but not in cells expressing the WT $(1.586 \pm 2.496 \mathrm{pA})$ or T292I $(1.913 \pm 2.304 \mathrm{pA}) \mathrm{GABA}_{\mathrm{A}}$ Rs (Figure 5A,C). These results demonstrated that the T292S variant could increase both tonic and leak currents of $\mathrm{GABA}_{\mathrm{A}}$ Rs while the T292I variant could not affect either current.

\subsection{Thiocolchicoside Restores the Function of T292S GABA $A_{A} R$}

The increased GABA sensitivity of T292S variant is a surprising result since it suggests that a gain-of-function mutant of the $\mathrm{GABA}_{\mathrm{A}} \mathrm{R}$ is also pathogenic. We reasoned that negative $\mathrm{GABA}_{\mathrm{A}} \mathrm{R}$ modulators may be able to normalize the function of the mutant receptor back to the WT receptor level, thereby exhibiting therapeutic potential to treat patients carrying this gain-of-function $\mathrm{GABA}_{\mathrm{A}} \mathrm{R}$ variant. We examined the effect of three clinically approved negative allosteric $\mathrm{GABA}_{\mathrm{A}} \mathrm{R}$ modulators, bemegride [38], flumazenil [39], and thiocochicoside (TCC) [30], on the whole-cell currents evoked with perfusion of a range of 
GABA from $0.1 \mu \mathrm{M}$ to $1 \mathrm{mM}$. We found that among the three drugs tested at a concentration of $200 \mu \mathrm{M}$, only TCC was able to significantly reduce the increased GABA currents gated through the T292S variant (Figure 6A-D). We then tested the dose-response curve of TCC in decreasing T292S GABA $\mathrm{A}_{\mathrm{A}}$ gated currents evoked by $1 \mu \mathrm{M}$ GABA in an effort to find an optimal concentration of TCC that was capable of fully restoring the GABA-sensitivity of T292S GABA $\mathrm{A}$ R (Figure 6A,E and Supplemental Figure S3A,B). As shown in Figure 6A,E, we found that $1 \mu \mathrm{M}$ TCC was able to fully shift the dose-response curve leftward to the level of the WT GABA $\mathrm{R}$.

\subsection{Combination of Verapamil and Diazepam Partially Rescues the Function of T292I GABA $A_{A} R$}

Since the T292I variant's loss-of-function is primarily a result of reduced channelopening probability, we reasoned that its channel abnormality may be restored by some positive $\mathrm{GABA}_{\mathrm{A}} \mathrm{R}$ allosteric modulators, such as diazepam and verapamil, that have previously been shown to restore the function of some pathogenic loss-of-function $G_{A B A} R$ variants via improving channel-gating properties [20]. We first pretreated HEK293 cells transiently expressing the $\alpha 1_{\mathrm{T} 292 \mathrm{I}} / \beta 2 / \gamma 2$ receptors with verapamil $(4 \mu \mathrm{M})$ for $24 \mathrm{~h}$, as well as acutely applied verapamil during the recordings of the full dose response of the GABA-evoked currents. As shown in Figure 7A,C, verapamil showed slight rescuing effects

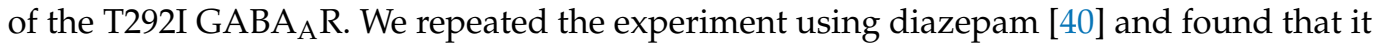
also only showed partial rescuing effects (Figure 7A,B). Then, we considered the possibility that a combination of verapamil and diazepam would result in a synergistic rescuing effect. Indeed, acute application of diazepam and verapamil together after chronic treatment of verapamil showed the best effect in shifting the GABA-evoked dose-response curve toward that of the WT counterpart (Figure 7A,D), although the shift remained incomplete.

A
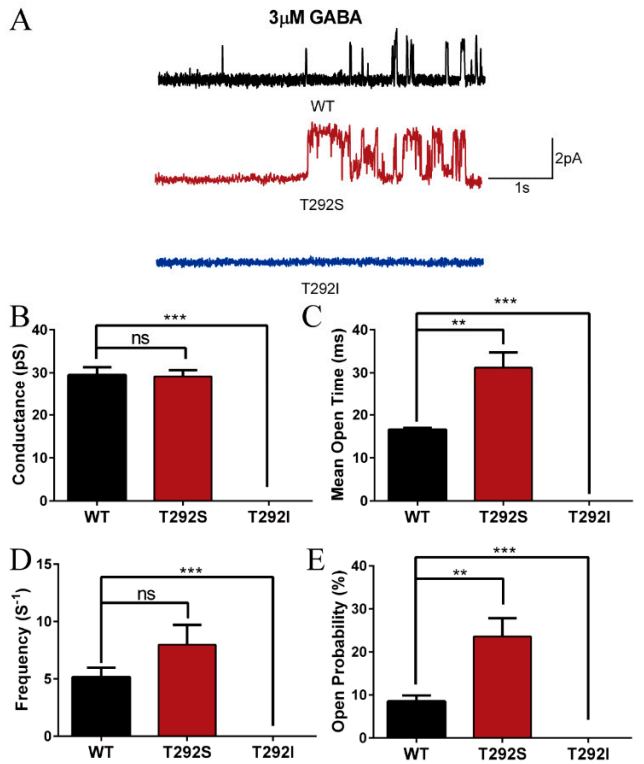

F

1mM GABA
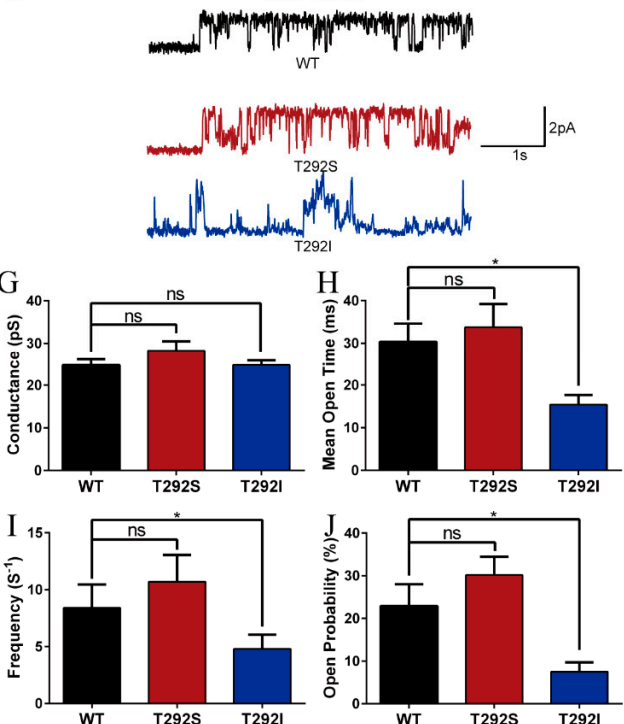

Figure 4. T292S and T292I variants bidirectionally altered $\mathrm{GABA}_{\mathrm{A}} \mathrm{R}$ single-channel properties. Cellattached single-channel currents were recorded for WT (black), $\alpha 1_{\mathrm{T} 292 \mathrm{~S}}$ (red), and $\alpha 1_{\mathrm{T} 292 \mathrm{I}}$ (blue) of $\mathrm{GABA}_{\mathrm{A}} \mathrm{R}$ under subsaturating and saturating concentrations of GABA. (A) Representative trace of $\alpha 1_{\mathrm{T} 292 \mathrm{~S}}(n=6), \alpha 1_{\mathrm{T} 292 \mathrm{I}}(n=6)$, and WT $(n=6) \mathrm{GABA}_{\mathrm{A}} \mathrm{R}$ under $3 \mu \mathrm{M}$ GABA. (B) Conductance under $3 \mu \mathrm{M}$ GABA condition. (C) Mean open time under $3 \mu \mathrm{M}$ GABA condition. (D) Channelopening frequency under $3 \mu \mathrm{M}$ GABA condition. (E) Open probability under $3 \mu \mathrm{M}$ GABA condition. (F) Representative trace of $\alpha 1_{\mathrm{T} 292 \mathrm{~S}}(n=6), \alpha 1_{\mathrm{T} 292 \mathrm{I}}(n=6)$, and WT $(n=8) \mathrm{GABA}_{\mathrm{A}} \mathrm{R}$ under $1 \mathrm{mM}$ GABA. (G) Conductance under $1 \mathrm{mM}$ GABA condition. (H) Mean open time under $1 \mathrm{mM}$ GABA condition. (I) Channel-opening frequency under $1 \mathrm{mM}$ GABA condition. (J) Open probability under $1 \mathrm{mM}$ GABA condition. Statistical differences were determined using one-way ANOVA $\left({ }^{*} p<0.05\right.$, ${ }^{* *} p<0.01,{ }^{* * *} p<0.001, \mathrm{~ns}=$ not significant). 
A

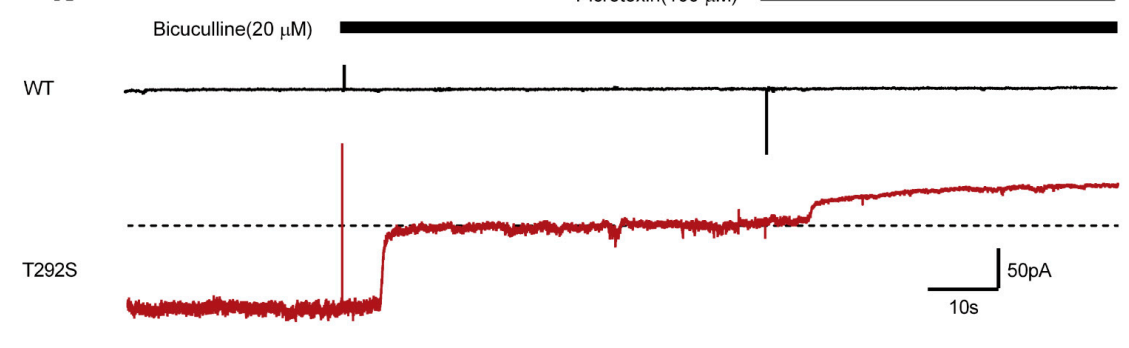

T2921
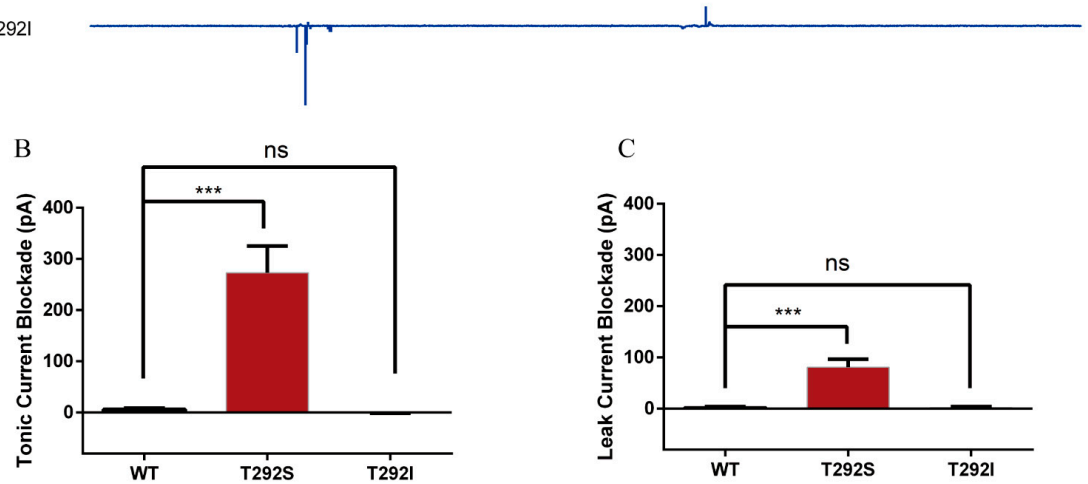

Figure 5. Tonic and leak current assays on $\mathrm{WT}, \alpha 1_{\mathrm{T} 292 \mathrm{~S}}$, and $\alpha 1_{\mathrm{T} 292 \mathrm{I}}$ of $\mathrm{GABA}_{\mathrm{A}} \mathrm{R}$ show increased tonic and leak currents in the T292S mutant receptor. (A) Representative trace of bicuculline-blocked tonic current and picrotoxin-blocked leak current of WT, $\alpha 1_{\mathrm{T} 292 \mathrm{~S}}$, and $\alpha 1_{\mathrm{T} 292 \mathrm{I}} \mathrm{GABA}_{\mathrm{A}} \mathrm{R}$. Dotted line indicates the new baseline after tonic current fully blocked by $20 \mu \mathrm{M}$ bicuculline for the quantification of additional $100 \mu \mathrm{M}$ picrotoxin-blocked leak current. (B) Quantification of tonic current blocked by bicuculline in WT $(n=5), \alpha 1_{\mathrm{T} 292 \mathrm{~S}}(n=9)$, and $\alpha 1_{\mathrm{T} 292 \mathrm{I}}(n=8)$ of GABA $\mathrm{G}$. (C) Quantification of leak current blocked by picrotoxin in WT $(n=5), \alpha 1_{\mathrm{T} 292 \mathrm{~S}}(n=8)$, and $\alpha 1_{\mathrm{T} 292 \mathrm{I}}(n=7)$ of GABA $_{\mathrm{A}} \mathrm{R}$. Statistical differences were determined using one-way ANOVA $\left({ }^{* * *} p<0.001\right.$, ns $=$ not significant).

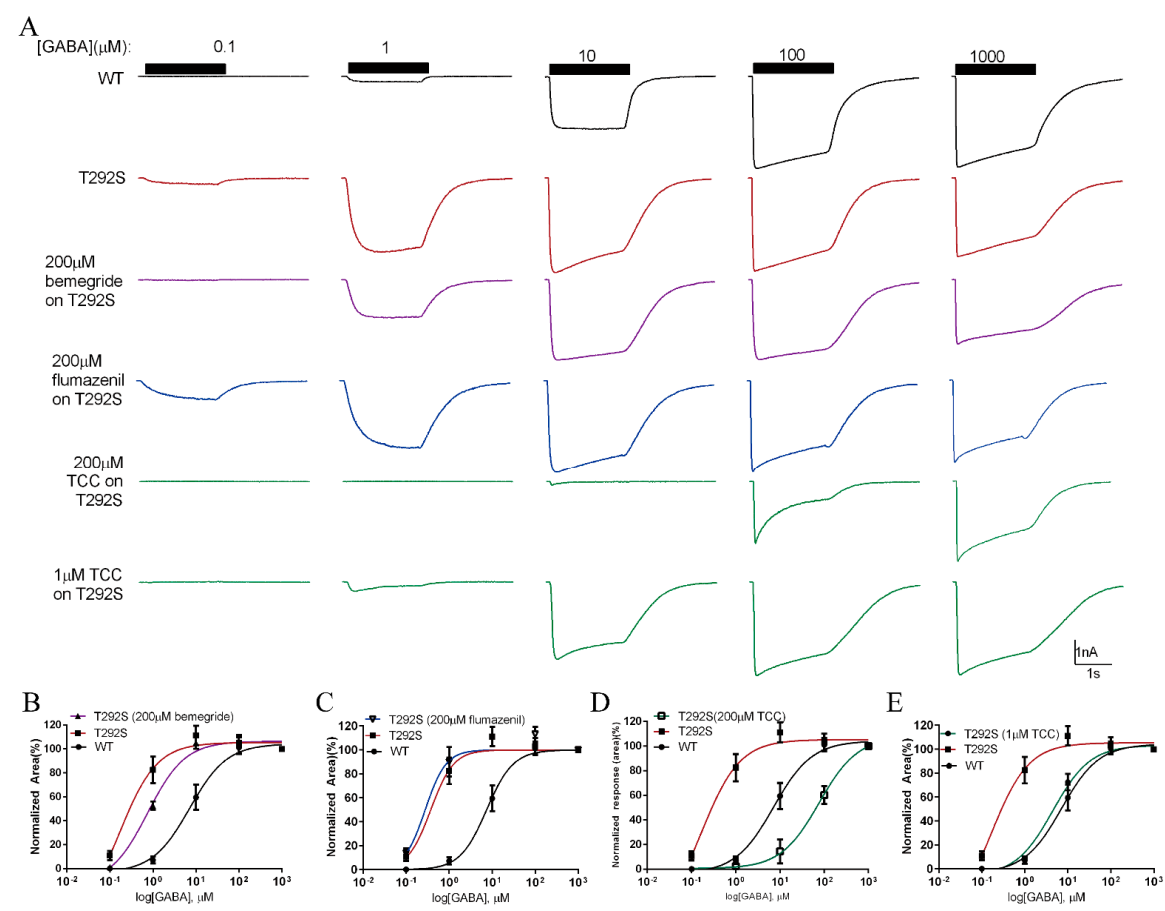

Figure 6. The restoring effects of the negative $\mathrm{GABA}_{\mathrm{A}} \mathrm{R}$ allosteric modulators on $\alpha 1_{\mathrm{T} 292 \mathrm{~S}}$ mutant $\mathrm{GABA}_{\mathrm{A}}$ R. (A) Representative trace of GABA-evoked currents of the WT (black), $\alpha 1_{\mathrm{T} 292 \mathrm{~S}}$ (red), and 
$\alpha 1_{\mathrm{T} 292 \mathrm{~S}} \mathrm{GABA}_{\mathrm{A}} \mathrm{R}$ treated by bemegride (purple), flumazenil (blue), and thiocochicoside (TCC) (green). (B) Dose-response curve of $\alpha 1_{\mathrm{T} 292 \mathrm{~S}} \mathrm{GABA}_{\mathrm{A}} \mathrm{R}$ treated with bemegride $(n=5)$ in comparison with untreated $\alpha 1 \mathrm{~T} 292 \mathrm{~S}(n=8)$ and WT $(n=10) \mathrm{GABA}_{\mathrm{A}}$ Rs. $(\mathrm{C})$ Dose-response curve of $\alpha 1_{\mathrm{T} 292 \mathrm{~S}} \mathrm{GABA}_{\mathrm{A}} \mathrm{R}$ treated by flumazenil $(n=6)$ in comparison with untreated $\alpha 1_{\mathrm{T} 292 \mathrm{~S}}(n=8)$ and WT $(n=10) \mathrm{GABA}_{\mathrm{A}}$ Rs. (D) Dose-response curve of $\alpha 1_{\text {T292S }}$ GABA $_{\mathrm{A}} \mathrm{R}$ with thiocochicoside (TCC) $(n=8)$ treatment compared with untreated $\alpha 1_{\mathrm{T} 292 \mathrm{~S}}(n=8)$ and WT $(n=10) \mathrm{GABA}_{\mathrm{A}}$ Rs. (E) Dose-response curve of $\alpha 1 \mathrm{~T} 292 \mathrm{~S}$ GABA $_{\mathrm{A}} \mathrm{R}$ with $1 \mu \mathrm{M}$ thiocochicoside (TCC) $(n=7)$ treatment compared with untreated $\alpha 1 \mathrm{~T} 292 \mathrm{~S}$ $(n=8)$ and WT $(n=10) \mathrm{GABA}_{\mathrm{A}}$ Rs.

A
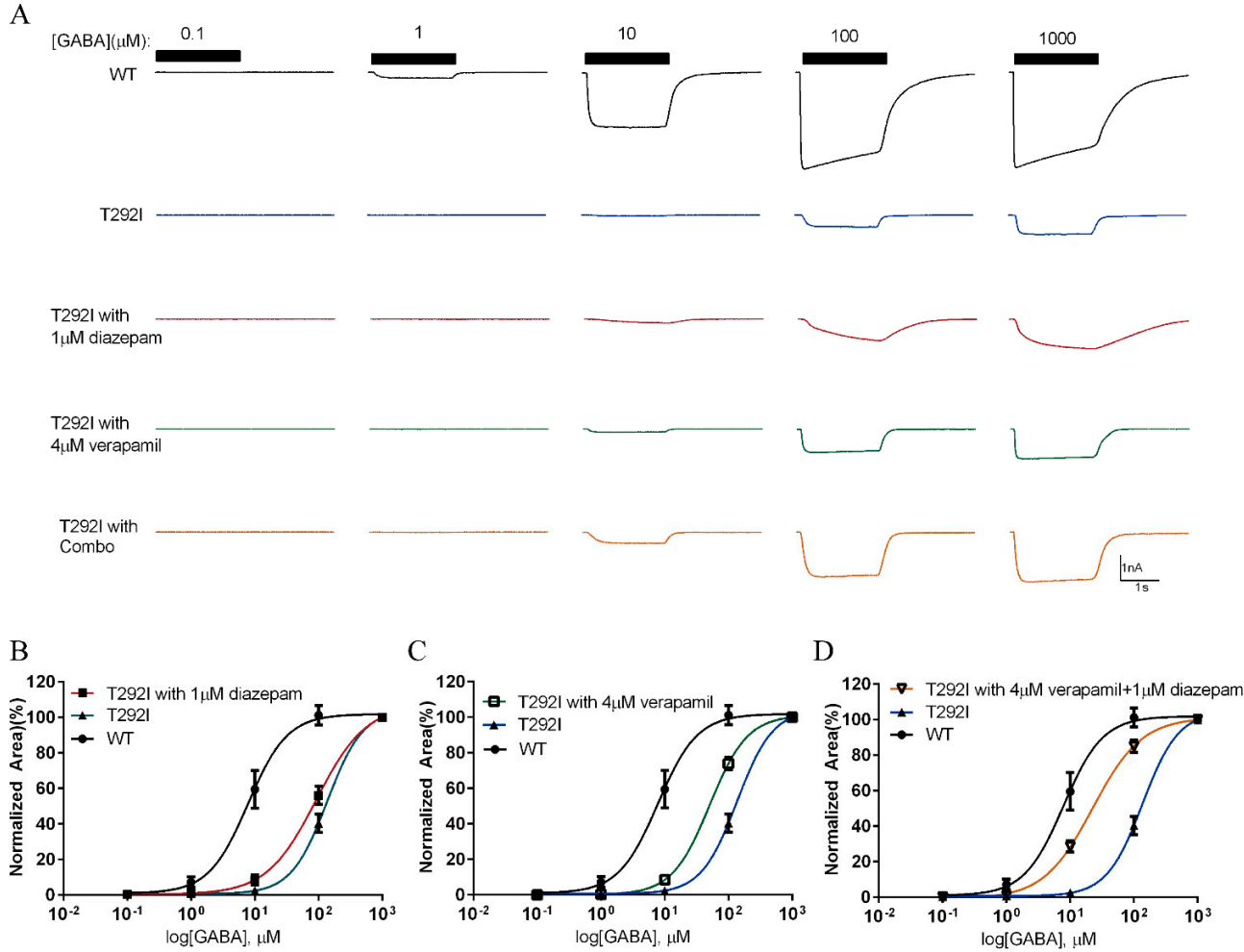

Figure 7. The rescuing effects of diazepam and verapamil on the $\alpha 1_{\text {T292I }}$ mutant $G A B A_{A} R$. (A) Representative trace of GABA-evoked currents of WT (black), $\alpha 1_{\text {T292I }}$ (blue) GABA $\mathrm{R}$, and $\alpha 1_{\text {T292I }}$ with treatment of diazepam (red), verapamil (green), and the combination of both (orange). (B) Dose-response curve of $\alpha 1_{\mathrm{T} 292 \mathrm{I}} \mathrm{GABA}_{\mathrm{A}} \mathrm{R}$ with diazepam $(n=6)$ in comparison with untreated $\alpha 1_{\text {T292I }}(n=8)$ and WT $(n=10)$ GABA $_{\mathrm{A}}$ Rs. (C) Dose-response curve of $\alpha 1_{\mathrm{T} 292 \mathrm{I}} \mathrm{GABA}_{\mathrm{A}} \mathrm{R}$ with verapamil $(n=7)$ treatment in comparison with untreated $\alpha 1_{\mathrm{T} 292 \mathrm{I}}(n=8)$ and WT $(n=10) \mathrm{GABA}_{\mathrm{A}}$ Rs. (D) Dose-response curve of $\alpha 1$ T292I GABA $\mathrm{R}$ with combined treatments of diazepam and verapamil $(n=8)$ compared with untreated $\alpha 1_{\mathrm{T} 292 \mathrm{I}}(n=8)$ and WT $(n=10) \mathrm{GABA}_{\mathrm{A}}$ Rs.

\section{Discussion}

In this study, we reported a novel de novo missense variant T292S of the T292 residue of GABRA1 and compared it with a previously found de novo missense variant T292I of the same residue. As summarized in Table 1, clinical observations and laboratory investigations revealed drastically distinct clinical phenotypes and functional alterations in these $\mathrm{GABA}_{\mathrm{A}}$ Rs mutants. The patient carrying the T292S variant is featured with developmental delay without observable somatic seizure activity until deceased (while the possibility that epileptic activity could develop at a later developmental stage cannot be entirely ruled out); while the patient with the T292I variant primarily manifested with severe epilepsy $[19,31]$. Considering the fact the T292 residue is highly conserved among species and is one of the residues lining the channel pore, functional characterization of these variants identified from patients may improve our understanding of the underlying pathophysiology. Our functional analysis performed in HEK293 cells showed that the T292S and T292I variants of the $\mathrm{GABA}_{\mathrm{A}} \mathrm{R} \alpha 1$ subunit conferred opposing changes in 
GABA agonist sensitivity and potency. The T292S variant induced a leftward shift of the GABA dose-response curve and lowered the $\mathrm{EC}_{50}$ of GABA without altering the maximum response. On the other hand, the T292I variant caused a rightward shift of the GABA dose-response curve, increased the $\mathrm{EC}_{50}$ of $\mathrm{GABA}$, and reduced the maximum response. To our knowledge, this is the first study that performs detailed functional characterizations of the T292S and T292I variants, and importantly, the first to report that the same subunit residue of $\mathrm{GABA}_{\mathrm{A}} \mathrm{R}$ replaced by different amino acids would result in opposite impacts on the receptor functions.

Table 1. Summary of the $\mathrm{GABA}_{\mathrm{A}} \mathrm{R}$ functional alterations of the T292S and T292I variants and clinical phenotypes of the two patients carrying these two mutations. (up and down arrows indicate increase and decrease respectively).

\begin{tabular}{|c|c|c|}
\hline & Patient 1 (Present Study) & Patient $2[19,31]$ \\
\hline Onset age & 6 months (developmental delay) & 3 months (epilepsy) \\
\hline Detection method & Whole exome sequencing & Whole exome sequencing \\
\hline Nucleotide change & NM000806.5: c.875 C>G & NM000806.5: c.875 C>T \\
\hline Protein change & p.Thr292Ser & p.Thr292Ile \\
\hline Inheritance & De novo & De novo \\
\hline Clinical features & $\begin{array}{l}\text { No diagnosed seizure events } \\
\text { Developmental delay }\end{array}$ & $\begin{array}{l}\text { Lennox-Gastaut syndrome } \\
\text { with light-sensitive myoclonic } \\
\text { epilepsy and generalized } \\
\text { tonic-clonic seizures }\end{array}$ \\
\hline EEG & a few abnormal discharge & $\mathrm{N} / \mathrm{A}$ \\
\hline MRI & Normal & $\mathrm{N} / \mathrm{A}$ \\
\hline Functional alterations & $\begin{array}{c}\text { Agonist sensitivity } \uparrow \\
\text { Maximum response: normal } \\
\text { Surface/total expression: normal } \\
\text { Channel open probability } \uparrow \\
\text { Tonic and leak current } \uparrow\end{array}$ & $\begin{array}{c}\text { Agonist sensitivity } \\
\text { Maximum response } \downarrow \\
\text { EC50 } \\
\text { Surface/total } \\
\text { expression: normal } \\
\text { Channel open probability } \downarrow \\
\text { Tonic and leak current: normal }\end{array}$ \\
\hline
\end{tabular}

There are several potential reasons that can explain these functional changes, which were examined in detail in our experiments [22]. First, the genetic mutations observed in the GABARA1 variants may theoretically alter the receptor expression, assembly, and trafficking that lead to the change of the surface/total receptor numbers [20]. However, we found that neither T292S nor T292I variants caused changes in the receptor numbers as evidenced by the results of immunoblotting and surface biotinylation assays.

Second, single amino acid mutations may induce structural changes in the GABA agonist-binding pocket and result in increased or decreased GABA binding affinity $[22,24,41]$. However, as the T292 residue is located at the inner channel pore, which is located far from the GABA binding region, the chance that the mutation causes an allosteric change in the structure of the GABA agonist-binding pocket is low.

Third, since this residue lies in the middle of the channel pore, its mutations may produce conformational changes that lead to altered GABA sensitivity in inducing channel gating $[24,28]$. Supporting this conjecture, our single-channel recording data showed significant changes in channel-gating properties in both variants. The T292S variant increased the single-channel open time and open probability under subsaturating $(3 \mu \mathrm{M})$ and saturating $(1 \mathrm{mM}) \mathrm{GABA}$ concentrations, suggesting the alteration of $\mathrm{GABA}_{\mathrm{A}} \mathrm{R}$ function by increasing the sensitivity of GABA to induce channel opening. In contrast, the T292I variant showed a significant decrease in GABA's ability to keep the channel opened as evident by the lack 
of opening activity at the subsaturating GABA level, and significantly reduced channel open time and open probability at the saturating GABA stimulation (1mM). Together, these results strongly suggest that residue T292 in the $\alpha 1$ subunit has a critical role in determining the channel open threshold by its agonists. The idea that the opposing functional alterations of these two mutations primarily resulted in changing GABA's sensitivity in gating the receptor channel is further supported by the results of our tonic and leak currents assay. We found that the T292S (but not T92I) GABA $\mathrm{R}$ showed increased tonic currents and leak currents. We postulated that the T292S variant not only decreases the threshold of GABA-induced channel opening, but also keeps the channel at a partially opened status even in the absence of agonist binding, whereas the T292I variant turns the channel into a more closed status by decreasing the channel opening ability. Given that the T292 residue is located at the TM2 segment and forms part of the channel pore, it should not be surprising to see such changes in the channel-gating properties. In particular, the T292I variant involves a threonine to isoleucine mutation, which may result in a significant change in the side chain's length and polarity that are not in favour of channel opening. Similarly, as the T292S variant involves a more subtle threonine to serine mutation, it results in less alteration in the side chain's length and polarity, and such relative subtle changes may, in turn, favour channel opening. Together, the ability of both T292S and T292I to dramatically and oppositely change the channel open probability demonstrates that $\alpha 1 \mathrm{~T} 292$ is a critical residue for controlling $\mathrm{GABA}_{\mathrm{A}} \mathrm{R}$ channel gating.

Since we identified the first GABRA1 mutation, A322D, in an epilepsy patient two decades ago [42], there have been more than 25 GABRA1 mutations that are related to pediatric encephalopathy reported, such as T20I, V74I, S76R, F104C, R112Q, N115D, L146M, T156C, P181S, D219N, P260L, S270H, V287L, T292I, K306T A322D, A332V, as well as $\mathrm{R} 214 \mathrm{H} / \mathrm{C}, \mathrm{G} 251 \mathrm{~S} / \mathrm{D}, \mathrm{M} 263 \mathrm{~T} / \mathrm{I}$, and T289P/A, in which the same residue is replaced by different amino acids $[8,13,21,25,35,43]$. Most of these characterized mutations cause a loss of function of the $\mathrm{GABA}_{\mathrm{A}} \mathrm{R}$ due to reduced surface/total expression, decreased agonist sensitivity, or compromised channel gating $[20,42,44,45]$. In addition to our T292S variant reported here, only one of these GABRA1 variants, A332V, which is located in the channel pore-forming TM3, is recently reported to enhance the receptor function [41]. In the present work, we report for the first time that the T292S variant, unlike most of the previously reported pathogenic $\mathrm{GABA}_{\mathrm{A}} \mathrm{R}$ variants, is clearly a gain-of-function variant; while the T292I variant, which occurs at the same residue with a different amino acid substitution as T292S, is a loss-of-function variant.

Following functional profiling of the pathological mechanisms of the T292S and T292I mutations, we also attempted to identify potential therapeutic options for more effective and personalized treatments. Guided by the detailed functional phenotypes of the two variants, we performed a quick screening of some clinically approved drugs that directly or indirectly act on $\mathrm{GABA}_{\mathrm{A}}$ Rs that may potentially reduce the functional abnormalities of certain mutants of $\mathrm{GABA}_{\mathrm{A}}$ Rs. Thiocochicoside (TCC) is used in the clinic as a muscle relaxant, but it is also an allosteric $\mathrm{GABA}_{\mathrm{A}} \mathrm{R}$ inhibitor that shows potent antagonistic effects against $\mathrm{GABA}_{\mathrm{A}} \mathrm{R}$ [30]. At a $1 \mu \mathrm{M}$ concentration, TCC could fully restore the increased GABA-evoked dose response of the T292S variant to the WT level, with superior effects over other $\mathrm{GABA}_{\mathrm{A}} \mathrm{R}$ negative allosteric modulators, bemegride and flumazenil. Our study, along with other previous studies, suggest that TCC can be a potential therapeutic option for gain-of-function $\mathrm{GABA}_{\mathrm{A}} \mathrm{R}$ variants [22,41].

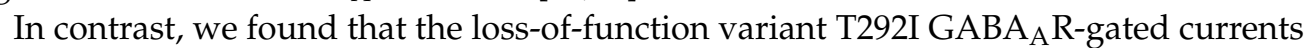
could be partially restored by a combination of two positive $G_{A B A} R$ modulating drugs, diazepam and verapamil. Chronic treatment of verapamil was shown to enhance channel gating with an elongated open time and increased open probability of R214C GABA $R$, suggesting diazepam and verapamil may work synergistically to ultimately improve the function of the T292I variant $\mathrm{GABA}_{\mathrm{A}}$ Rs. Our study indicates that these mutations have opposite impacts on the function of $\mathrm{GABA}_{\mathrm{A}} \mathrm{Rs}$, and although occurring at the same residue, thereby require different functional and pharmacological strategies to restore the function 
of the receptor to the level of their WT counterpart. Thus, our findings suggest that it is of paramount importance to perform functional and pharmacological analysis after exome sequencing to determine the pathological mechanisms. This would aid in searching for the appropriate therapeutic options for patients carrying a de novo mutation of principle neurotransmitter receptors, such as the $\mathrm{GABA}_{\mathrm{A}} \mathrm{Rs}$.

In conclusion, our functional analyses of the two de novo variants, T292S and T292I, of the same GABRA1 T292 residue from two patients with distinct clinical phenotypes have revealed their gain-of-function and loss-of-function impacts on the $\mathrm{GABA}_{\mathrm{A}} \mathrm{R}$, respectively. The study not only provides evidence for the pathogenic contributions of the two variants to the patients' pathology, but also indicates the crucial role of the T292 residue in controlling channel gating. There are around $30 \%$ of children with refractory epilepsy that do not respond to conventional drug treatments due to unknown functional alterations or unidentified causes [46,47]. Moreover, traditional anti-seizure drugs show little to no effect toward rescuing deficits caused by specific mutations in the $\mathrm{GABA}_{\mathrm{A}} \mathrm{R}$ subunits $[48,49]$, and in certain cases, can even exacerbate the symptoms [50,51]. The pharmacological characterizations in our study provide differential therapeutic suggestions for managing these two patients and endorse the importance of precision medicine for pediatric channelopathies.

\section{Materials and Methods}

\subsection{Structural Modeling of $G A B A_{A}$ Receptor}

The crystal structure of the $\mathrm{GABA}_{\mathrm{A}} \mathrm{R}$ was obtained from the Protein Data Bank (PDB) (ID: 6X3U) [52]. Molecular graphics and analyses were performed with the PyMOL Academic-Professional version (Schrödinger, Inc., New York, NY, USA).

\subsection{Plasmid Construction}

The cDNAs encoding rat $\mathrm{GABA}_{\mathrm{A}} \mathrm{R} \alpha 1, \mathrm{GABA}_{\mathrm{A}} \mathrm{R} \beta 2, \mathrm{GABA}_{\mathrm{A}} \mathrm{R} \gamma 2$, and EGFP were separately cloned into the pcDNA3.0 vector (Invitrogen, Waltham, MA, USA). Using the plasmid with the WT rat $\mathrm{GABA}_{\mathrm{A}} \mathrm{R} \alpha 1 \mathrm{cDNA}$ as the template, PCR mediated QuickChange site-directed mutagenesis was performed with a high-fidelity Hot Start DNA polymerase (KAPA Biosystmems, Wilmington, MA, USA Cat: KM2605) to construct the mutated variants of the $\mathrm{GABA}_{\mathrm{A}} \mathrm{R} \alpha 1$ (c.875 $\mathrm{C}>\mathrm{G}$ and c. $875 \mathrm{C}>\mathrm{T}$ ) subunit (point mutation primers: Sense $5^{\prime}$-cgaccgttctgagcatgacaacctt- $3^{\prime}$, reverse $5^{\prime}$-aaggttgtcatgctcagaacggtcg- $3^{\prime}$ and sense $5^{\prime}$-cgaccgttctgatcatgacaacctt- $3^{\prime}$, reverse $5^{\prime}$-aaggttgtcatgatcagaacggtcg- $3^{\prime}$ for T292S and T292I mutations, respectively). The mutations were confirmed by sequencing, and the resulting plasmids encoding the mutant $\mathrm{GABA}_{\mathrm{A}} \mathrm{R} \alpha 1$ were referred to as $\alpha 1_{\mathrm{T} 292 \mathrm{~S}}$ (T292S) and

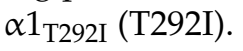

\subsection{Cell Culture and Transfection}

HEK293 cells were cultured in Dulbecco's Modified Eagle Medium (DMEM; MilliporeSigma, St. Louis, MO, USA) supplemented with $10 \%$ fetal bovine serum (FBS; Invitrogen, Waltham, MA, USA). The cells were maintained at $37^{\circ} \mathrm{C}$ with $5 \% \mathrm{CO}_{2}$. For Western blot experiments investigating the expression of the GABA $\mathrm{R} \alpha_{1}$ subunits, cells were grown to $70 \%$ confluency in a poly-L-lysine-coated 6-well plate and co-transfected with plasmids en-

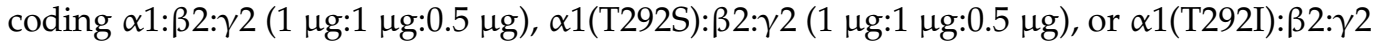
$(1 \mu \mathrm{g}: 1 \mu \mathrm{g}: 0.5 \mu \mathrm{g})$. The transfection was performed using the lipofectamine 2000 reagent (Invitrogen, Waltham, MA, USA) according to the manufacturer's instructions. Transfected HEK293 cells were cultured for $40 \mathrm{~h}$ and then used for downstream Western blotting analysis and surface biotinylation assays. For electrophysiology experiments, cells were grown to $70-90 \%$ confluency in 6-well plates. EGFP $(0.2 \mu \mathrm{g})$ plasmids were co-transfected with the $\mathrm{GABA}_{\mathrm{A}} \mathrm{R}$ subunits to help visualize the successfully transfected cells during electrophysiology recording. Cells were maintained in 6-well plates for $5 \mathrm{~h}$ before being re-plated onto $12 \mathrm{~mm}$ glass coverslips coated with poly-L-lysine and were cultured for an additional 18-30 $\mathrm{h}$ before recording. 


\subsection{Western Blot and Surface Biotinylation}

Transfected HEK293 cells in a 6-well cell culture plate were washed with ice-cold PBS three times and lysed with $0.5 \mathrm{~mL}$ of $1 \%$ SDS TBS buffer containing a protease inhibitor cocktail (Bimake, Houston, TX, USA) at $4{ }^{\circ} \mathrm{C}$ for $30 \mathrm{~min}$. Cells were then harvested and homogenized using needles with gauge sizes from $18 \mathrm{G}$ to $23 \mathrm{G}$ to $26 \mathrm{G}$, progressively. The supernatant was collected after centrifugation $\left(13,000 \mathrm{rpm}, 4^{\circ} \mathrm{C}, 10 \mathrm{~min}\right)$ and the protein concentration in each sample was measured using the Pierce BCA protein assay (Thermo Scientific, Waltham, MA, USA, REP233228). Samples containing equal amounts of the total protein were treated with the 6X Laemmli sample buffer containing $9 \%$ betamercaptoethanol (MilliporeSigma, St. Louis, MO, USA) and heated at $55^{\circ} \mathrm{C}$ for 5 min before loading onto $10 \%$ SDS-PAGE gels. The proteins in the gels were transferred onto a PVDF membrane (MilliporeSigma, St. Louis, MO, USA). Rabbit anti-GABA ${ }_{\mathrm{A}} \mathrm{R} \alpha 1$ polyclonal antibody (1:1000, MilliporeSigma, St. Louis, MO, USA, Cat. \#06-868) was used to detect the WT and variant $\mathrm{GABA}_{\mathrm{A}} \mathrm{R} \alpha 1$ subunits. HSP90 (mouse monoclonal antibody 1:4000, BD, Biosciences, Franklin Lakes, NJ, USA, Cat. \#610418) served as the loading control. The HRP-conjugated anti-mouse or anti-rabbit secondary antibodies (Thermo-Fisher Scientific, Waltham, MA, USA, Cat. \# 31430 and 31460) were used in a ratio of 1:5000. The signal was detected using an ECL detection system (MilliporeSigma, St. Louis, MO, USA, Immobilon Crescendo Western HPP Substrate, Cat\#WBLUR0500) via Bio-Rad ChemiDoc MP imaging system.

In the surface biotinylation assay, cells in a 6-well cell culture plate were washed 3 times on ice with ice-cold PBS $40 \mathrm{~h}$ post-transfection, then $0.5 \mathrm{~mL}$ of PBS with the membrane-impermeable reagent EZ-Link Sulfo-HNS-LC-Biotin (1 mg/mL, Thermo Scientific, Waltham, MA, USA) was added into each well and kept at $4{ }^{\circ} \mathrm{C}$ for 30 min to label surface membrane proteins. To quench the biotin reaction, cells were washed on ice with $1 \mathrm{~mL}$ of $100 \mathrm{mM}$ glycine dissolved in ice-cold PBS three times (10 min each time) at $4{ }^{\circ} \mathrm{C}$. Then the biotinylated cells in each well were harvested using $0.5 \mathrm{~mL}$ of $1 \%$ SDS lysate buffer (1\% SDS in 1XTris Buffered saline, $\mathrm{pH} 7.6)$ ) at $4{ }^{\circ} \mathrm{C}$ for $30 \mathrm{~min}$ and homogenized using needles with a gauge size from G18 to G23 to G26, progressively. Supernatants were collected after centrifugation $\left(13,000 \mathrm{rpm}, 4{ }^{\circ} \mathrm{C}, 10 \mathrm{~min}\right)$. The protein concentration in each sample was measured using the Pierce BCA protein assay (Thermo scientific, Waltham, MA, USA REP233228). Each sample with an equal amount of biotin-labeled membrane proteins was rotationally incubated with $30 \mathrm{uL}$ of High-Capacity Streptavidin Agarose Resin (beads) (Thermo Scientific, Waltham, MA, USA REF20359) at $4{ }^{\circ} \mathrm{C}$ overnight, after which the beads were pulled down and washed with PBS for 3-4 times via centrifugation (500 g, $4^{\circ} \mathrm{C}, 2 \mathrm{~min}$ ). The beads were suspended with $45 \mathrm{uL}$ of $2 X$ Laemmli sample buffer and heated at $55^{\circ} \mathrm{C}$ for $5 \mathrm{~min}$. Heated samples were then centrifuged at $1000 \mathrm{rpm}$ for $2 \mathrm{~min}$. Finally, the supernatants were loaded onto $10 \%$ SDS-PAGE gels. $\mathrm{Na}^{+} / \mathrm{K}^{+}$ATPase (abcam: Mouse monoclonal antibody alpha1 sodium potassium ATPase ([464.6] 1:1000) served as a loading control for the biotinylated membrane proteins and $\beta$-actin (MilliporeSigma, St. Louis, MO, USA: Mouse monoclonal antibody 1:3000, Cat, \#A2228) served as a labeling control for the cytoplasmic proteins.

\subsection{Electrophysiology}

Electrophysiology experiments, including whole-cell voltage-clamp recordings and cell-attached single-channel recordings, were performed at room temperature on HEK293 cells transfected with the WT, T292S, or T292I GABA $\mathrm{R}$ subunits. The recordings were conducted and low-pass-filtered at $2 \mathrm{kHz}$ using a MultiClamp 700A amplifier (Molecular Devices, San Jose, CA, USA) and digitized at $20 \mathrm{kHz}$ using Digidata 1440A. The recordings were performed using Clampex 10.7 software (Molecular Devices, San Jose, CA, USA) and the data were analyzed offline using Clampfit 10.7 (Molecular Devices, San Jose, CA, USA).

Whole-cell voltage clamp recordings were performed using an extracellular recording solution containing (in $\mathrm{mM}$ ) $140 \mathrm{NaCl}, 5.4 \mathrm{KCl}, 2 \mathrm{MgCl}_{2}, 1.3 \mathrm{CaCl}_{2}, 10 \mathrm{HEPES}$, and 33 glucose $(\mathrm{pH}=7.4,310-320 \mathrm{mOsm})$. The thin-walled borosilicate glass patch pipettes 
(World Precision Instruments, Sarasota, FL, USA) were pulled to 3-5 M $\Omega$ resistance using a model P-97 micropipette puller (Sutter Instruments, Novato, CA, USA). During the recording, the glass patch pipettes were filled with an internal solution containing (in $\mathrm{mM}) 140 \mathrm{CsCl}, 0.1 \mathrm{CaCl}_{2}, 2 \mathrm{MgCl}_{2}, 10 \mathrm{HEPES}, 0.5$ EGTA, and 4 ATP $(\mathrm{K})(\mathrm{pH}=7.2$, 290-300 mOsm). For the GABA dose-response curve, the holding voltage was set at $-60 \mathrm{mV}$, and $\mathrm{GABA}_{\mathrm{a}} \mathrm{R}$-gated currents were induced by applying various concentrations of GABA $(0.1 \mu \mathrm{M}-1000 \mu \mathrm{M}, 2 \mathrm{~s})$ using a two-barrel fast step perfusion system (Warner Instruments, Hamden, CT, USA). For the $\mathrm{GABA}_{\mathrm{A}} \mathrm{R}$ current-voltage (I/V) relationship experiment, the holding voltages were set at (in $\mathrm{mV})-80,-60,-40,-20,0,+20,+40,+60$, and +80 while applying a high concentration of GABA $(1 \mathrm{mM}, 1 \mathrm{~s})$.

Tonic and leak currents assay was performed using a bath solution exchange protocol. Specifically, cells were patched and then recorded using a gap-free program, where $10 \mu \mathrm{M}$ GABA, GABA-free ECS, $20 \mu \mathrm{M}$ bicuculline, and $20 \mu \mathrm{M}$ bicuculline plus $100 \mu \mathrm{M}$ picrotoxin were bath applied sequentially and the application of each solution lasted at least $60 \mathrm{~s}$ to allow enough time for solution exchanges in the chamber. The initial application of GABA was meant to confirm the success of transfection of the recombinant $\mathrm{GABA}_{\mathrm{A}} \mathrm{Rs}$.

Cell-attached single-channel recordings were conducted using the same protocol as before [15]. The patch electrodes were fire-polished to a resistance of 10-20 $\mathrm{M} \Omega$ and filled with the extracellular recording solution with $3 \mu \mathrm{M}$ or $1 \mathrm{mM}$ GABA $(\mathrm{pH}=7.4$, 310-320 mOsm), and the holding potential was $+100 \mathrm{mV}$. Single-channel events were detected using the 50\% amplitude threshold detection method and were visually inspected before being accepted. Single-channel open probability was determined by the fraction of open time over the total amount of analyzed time (120 s for each recording), and the mean channel open time was determined by the total amount of open time divided by the number of channel-opening events.

\subsection{Chemicals}

Picrotoxin (Abcam, Cambridge, UK), bemegride (Cedarlane, Burlington, ON, Canada), diazapem (Tocris Bioscience, Bristol, UK), and thiocolchicoside (Cedarlane, Burlington, ON, Canada) were first dissolved in DMSO for the stock solutions (100 mM) and further diluted in ECS to the desired working concentration during the experiment. Bicuculline (Hellobio Inc, Princeton, NJ, USA) and flumazenil (Tocris Bioscience, Bristol, UK) were first dissolved in DMSO for the stock solutions $(20 \mathrm{mM})$ and further diluted in ECS during the experiment. Verapamil hydrochloride (Tocris Bioscience, Bristol, UK) was diluted in water to make a $4 \mathrm{mM}$ stock solution.

\subsection{Data Analysis}

Data were presented as mean \pm SEM ( $n=$ number of cells). The unpaired $t$-test, one-way ANOVA, and two-way ANOVA (both ANOVAs were followed by Bonferroni post hoc tests) were used for statistical analysis, and ${ }^{*} p<0.05,{ }^{* *} p<0.01$, and ${ }^{* * *} p<0.001$ were considered statistically significant. Dose-response curves were fitted by the Hill equation, and $\mathrm{EC}_{50}$ was calculated by GraphPad prism 6 (GraphPad Software, San Diego, CA, USA). All data points were normalized to the maximum response of GABA-evoked current for each cell unless specified in the context. Whole-cell peak currents, the area under the curve, channel kinetics, and single-channel currents were analyzed by Clampfit 10.7(Molecular Devices, San Jose, CA, USA).

Supplementary Materials: The following supporting information can be downloaded at: https: / / www.mdpi.com/article/10.3390/ijms23052723/s1. 
Author Contributions: W.C., Y.G., J.L., Y.W.S., R.J., L.L. and Y.T.W. were involved in the conceptualization and design of the study. R.J. and J.M. collected clinical data. W.C. and Y.G. performed the electrophysiological experiments and J.L. performed molecular and biochemical experiments. W.C. analyzed and modified the structural model of the GABA ${ }_{A}$ Rs. W.C., Y.G., J.L., L.L. and Y.T.W. analyzed the data and prepared figures. W.C., Y.G., J.L., Y.W.S., L.L. and Y.T.W. wrote and revised the manuscript. All authors have read and agreed to the published version of the manuscript.

Funding: This work was supported by a Canadian Institutes of Health Research (CIHR) Foundation Grant (Funding \# FDN-154286) awarded to Yu Tian Wang. Yu Tian Wang is the holder of HSFBC\&Y Chair in Stroke Research.

Institutional Review Board Statement: Not applicable since all experiments conducted were not involving humans or animals.

Informed Consent Statement: Patient consent was waived due to the fact the clinical phenotypes described in this article are anonymous and without any sensitive information.

Data Availability Statement: Data are contained within the article or Supplementary Materials. Constructed plasmids are available upon request from the corresponding author.

Acknowledgments: We greatly appreciate the parents and primary clinical neurologists of the patient for their full support for this study. Wenlin Chen was supported by the China Scholarship Council (CSC)-Edwin S.H. Leong-UBC scholarship.

Conflicts of Interest: The authors declare no conflict of interest.

\section{References}

1. Thijs, R.D.; Surges, R.; O’Brien, T.J.; Sander, J.W. Epilepsy in adults. Lancet 2019, 393, 689-701. [CrossRef]

2. Arnold, S.T.; Dodson, W.E. Epilepsy in children. Bailliere's Clin. Neurol. 1996, 5, 783-802.

3. Devinsky, O.; Vezzani, A.; O’Brien, T.J.; Jette, N.; Scheffer, I.E.; de Curtis, M.; Perucca, P. Epilepsy. Nat. Rev. Dis. Primers 2018, 4, 18024. [CrossRef] [PubMed]

4. $\quad$ Wang, J.; Lin, Z.J.; Liu, L.; Xu, H.Q.; Shi, Y.W.; Yi, Y.H.; He, N.; Liao, W.P. Epilepsy-associated genes. Seizure 2017, 44, 11-20. [CrossRef] [PubMed]

5. Wei, F.; Yan, L.M.; Su, T.; He, N.; Lin, Z.J.; Wang, J.; Shi, Y.W.; Yi, Y.H.; Liao, W.P. Ion Channel Genes and Epilepsy: Functional Alteration, Pathogenic Potential, and Mechanism of Epilepsy. Neurosci. Bull. 2017, 33, 455-477. [CrossRef] [PubMed]

6. Krampfl, K.; Maljevic, S.; Cossette, P.; Ziegler, E.; Rouleau, G.A.; Lerche, H.; Bufler, J. Molecular analysis of the A322D mutation in the GABA receptor alpha-subunit causing juvenile myoclonic epilepsy. Eur. J. Neurosci. 2005, 22, 10-20. [CrossRef] [PubMed]

7. Gallagher, M.J.; Ding, L.; Maheshwari, A.; Macdonald, R.L. The GABAA receptor alpha1 subunit epilepsy mutation A322D inhibits transmembrane helix formation and causes proteasomal degradation. Proc. Natl. Acad. Sci. USA 2007, 104, 12999-13004. [CrossRef] [PubMed]

8. Ding, L.; Feng, H.J.; Macdonald, R.L.; Botzolakis, E.J.; Hu, N.; Gallagher, M.J. GABA(A) receptor alpha1 subunit mutation A322D associated with autosomal dominant juvenile myoclonic epilepsy reduces the expression and alters the composition of wild type GABA(A) receptors. J. Biol. Chem. 2010, 285, 26390-26405. [CrossRef] [PubMed]

9. Galanopoulou, A.S. GABA(A) receptors in normal development and seizures: Friends or foes? Curr. Neuropharmacol. 2008, 6, 1-20. [CrossRef] [PubMed]

10. Braat, S.; Kooy, R.F. The GABAA Receptor as a Therapeutic Target for Neurodevelopmental Disorders. Neuron 2015, 86, 1119-1130. [CrossRef]

11. He, Q.; Nomura, T.; Xu, J.; Contractor, A. The developmental switch in GABA polarity is delayed in fragile X mice. J. Neurosci. Off. J. Soc. Neurosci. 2014, 34, 446-450. [CrossRef] [PubMed]

12. Duarte, S.T.; Armstrong, J.; Roche, A.; Ortez, C.; Pérez, A.; O'Callaghan Mdel, M.; Pereira, A.; Sanmartí, F.; Ormazábal, A.; Artuch, R.; et al. Abnormal expression of cerebrospinal fluid cation chloride cotransporters in patients with Rett syndrome. PLoS ONE 2013, 8, e68851. [CrossRef] [PubMed]

13. Carvill, G.L.; Weckhuysen, S.; McMahon, J.M.; Hartmann, C.; Møller, R.S.; Hjalgrim, H.; Cook, J.; Geraghty, E.; O’Roak, B.J.; Petrou, S.; et al. GABRA1 and STXBP1: Novel genetic causes of Dravet syndrome. Neurology 2014, 82, 1245-1253. [CrossRef]

14. Pirker, S.; Schwarzer, C.; Wieselthaler, A.; Sieghart, W.; Sperk, G. GABA(A) receptors: Immunocytochemical distribution of 13 subunits in the adult rat brain. Neuroscience 2000, 101, 815-850. [CrossRef]

15. Collingridge, G.L.; Isaac, J.T.; Wang, Y.T. Receptor trafficking and synaptic plasticity. Nat. Rev. Neurosci. 2004, 5, 952-962. [CrossRef] [PubMed]

16. Michels, G.; Moss, S.J. GABAA receptors: Properties and trafficking. Crit. Rev. Biochem. Mol. Biol. 2007, 42, 3-14. [CrossRef] [PubMed] 
17. Sieghart, W.; Sperk, G. Subunit composition, distribution and function of GABA(A) receptor subtypes. Curr. Top. Med. Chem. 2002, 2, 795-816. [CrossRef] [PubMed]

18. Macdonald, R.L.; Olsen, R.W. GABAA receptor channels. Annu. Rev. Neurosci. 1994, 17, 569-602. [CrossRef]

19. Reyes-Nava, N.G.; Yu, H.C.; Coughlin, C.R., 2nd; Shaikh, T.H.; Quintana, A.M. Abnormal expression of GABA(A) receptor subunits and hypomotility upon loss of gabra1 in zebrafish. Biol. Open 2020, 9, bio051367. [CrossRef]

20. Bai, Y.F.; Chiu, M.; Chan, E.S.; Axerio-Cilies, P.; Lu, J.; Huh, L.; Connolly, M.B.; Guella, I.; Farrer, M.J.; Xu, Z.D.; et al. Pathophysiology of and therapeutic options for a GABRA1 variant linked to epileptic encephalopathy. Mol. Brain 2019, 12, 92. [CrossRef]

21. Hernandez, C.C.; XiangWei, W.; Hu, N.; Shen, D.; Shen, W.; Lagrange, A.H.; Zhang, Y.; Dai, L.; Ding, C.; Sun, Z.; et al. Altered inhibitory synapses in de novo GABRA5 and GABRA1 mutations associated with early onset epileptic encephalopathies. Brain $A$ J. Neurol. 2019, 142, 1938-1954. [CrossRef]

22. Butler, K.M.; Moody, O.A.; Schuler, E.; Coryell, J.; Alexander, J.J.; Jenkins, A.; Escayg, A. De novo variants in GABRA2 and GABRA5 alter receptor function and contribute to early-onset epilepsy. Brain A J. Neurol. 2018, 141, 2392-2405. [CrossRef] [PubMed]

23. Jacob, T.C.; Moss, S.J.; Jurd, R. GABA(A) receptor trafficking and its role in the dynamic modulation of neuronal inhibition. Nat. Rev. Neurosci. 2008, 9, 331-343. [CrossRef] [PubMed]

24. Janve, V.S.; Hernandez, C.C.; Verdier, K.M.; Hu, N.; Macdonald, R.L. Epileptic encephalopathy de novo GABRB mutations impair $\gamma$-aminobutyric acid type A receptor function. Ann. Neurol. 2016, 79, 806-825. [CrossRef] [PubMed]

25. Johannesen, K.; Marini, C.; Pfeffer, S.; Møller, R.S.; Dorn, T.; Niturad, C.E.; Gardella, E.; Weber, Y.; Søndergård, M.; Hjalgrim, H.; et al. Phenotypic spectrum of GABRA1: From generalized epilepsies to severe epileptic encephalopathies. Neurology 2016, 87, 1140-1151. [CrossRef]

26. Kodera, H.; Ohba, C.; Kato, M.; Maeda, T.; Araki, K.; Tajima, D.; Matsuo, M.; Hino-Fukuyo, N.; Kohashi, K.; Ishiyama, A.; et al. De novo GABRA1 mutations in Ohtahara and West syndromes. Epilepsia 2016, 57, 566-573. [CrossRef]

27. Maljevic, S.; Krampfl, K.; Cobilanschi, J.; Tilgen, N.; Beyer, S.; Weber, Y.G.; Schlesinger, F.; Ursu, D.; Melzer, W.; Cossette, P.; et al. A mutation in the GABA(A) receptor alpha(1)-subunit is associated with absence epilepsy. Ann. Neurol. 2006, 59, 983-987. [CrossRef]

28. Fisher, J.L. A mutation in the GABAA receptor alpha 1 subunit linked to human epilepsy affects channel gating properties Neuropharmacology 2004, 46, 629-637. [CrossRef]

29. Lachance-Touchette, P.; Choudhury, M.; Stoica, A.; Di Cristo, G.; Cossette, P. Single-cell genetic expression of mutant GABAA receptors causing Human genetic epilepsy alters dendritic spine and GABAergic bouton formation in a mutation-specific manner. Front. Cell. Neurosci. 2014, 8, 317. [CrossRef]

30. Carta, M.; Murru, L.; Botta, P.; Talani, G.; Sechi, G.; De Riu, P.; Sanna, E.; Biggio, G. The muscle relaxant thiocolchicoside is an antagonist of GABAA receptor function in the central nervous system. Neuropharmacology 2006, 51, 805-815. [CrossRef]

31. Allen, A.S.; Berkovic, S.F.; Cossette, P.; Delanty, N.; Dlugos, D.; Eichler, E.E.; Epstein, M.P.; Glauser, T.; Goldstein, D.B.; Han, Y.; et al. De novo mutations in epileptic encephalopathies. Nature 2013, 501, 217-221. [CrossRef]

32. Hernandez, C.C.; Kong, W.; Hu, N. Altered Channel Conductance States and Gating of GABA(A) Receptors by a Pore Mutation Linked to Dravet Syndrome. eNeuro 2017, 4, e025-16. [CrossRef] [PubMed]

33. Xu, M.; Akabas, M.H. Identification of channel-lining residues in the M2 membrane-spanning segment of the GABA(A) receptor alpha1 subunit. J. Gen. Physiol. 1996, 107, 195-205. [CrossRef]

34. Vithlani, M.; Terunuma, M.; Moss, S.J. The dynamic modulation of GABA(A) receptor trafficking and its role in regulating the plasticity of inhibitory synapses. Physiol. Rev. 2011, 91, 1009-1022. [CrossRef] [PubMed]

35. Bradley, C.A.; Taghibiglou, C.; Collingridge, G.L.; Wang, Y.T. Mechanisms involved in the reduction of GABAA receptor alpha1subunit expression caused by the epilepsy mutation A322D in the trafficking-competent receptor. J. Biol. Chem. 2008, 283, 22043-22050. [CrossRef] [PubMed]

36. Johnston, G.A. Advantages of an antagonist: Bicuculline and other GABA antagonists. Br. J. Pharmacol. 2013, 169, 328-336. [CrossRef]

37. Olsen, R.W. Allosteric ligands and their binding sites define $\gamma$-aminobutyric acid (GABA) type A receptor subtypes. Adv. Pharmacol. 2015, 73, 167-202. [CrossRef]

38. Mistry, D.K.; Cottrell, G.A. Actions of steroids and bemegride on the GABAA receptor of mouse spinal neurones in culture. Exp. Physiol. 1990, 75, 199-209. [CrossRef]

39. Safavynia, S.A.; Keating, G.; Speigel, I.; Fidler, J.A.; Kreuzer, M.; Rye, D.B.; Jenkins, A.; García, P.S. Effects of $\gamma$-Aminobutyric Acid Type A Receptor Modulation by Flumazenil on Emergence from General Anesthesia. Anesthesiology 2016, 125, 147-158. [CrossRef]

40. Olsen, R.W. GABA(A) receptor: Positive and negative allosteric modulators. Neuropharmacology 2018, 136, 10-22. [CrossRef]

41. Steudle, F.; Rehman, S.; Bampali, K. A novel de novo variant of GABRA1 causes increased sensitivity for GABA in vitro. Sci. Rep. 2020, 10, 2379. [CrossRef] [PubMed]

42. Cossette, P.; Liu, L.; Brisebois, K.; Dong, H.; Lortie, A.; Vanasse, M.; Saint-Hilaire, J.M.; Carmant, L.; Verner, A.; Lu, W.Y.; et al Mutation of GABRA1 in an autosomal dominant form of juvenile myoclonic epilepsy. Nat. Genet. 2002, 31, 184-189. [CrossRef] [PubMed] 
43. Liu, J.; Tong, L.; Song, S.; Niu, Y.; Li, J.; Wu, X.; Zhang, J.; Zai, C.C.; Luo, F.; Wu, J.; et al. Novel and de novo mutations in pediatric refractory epilepsy. Mol. Brain 2018, 11, 48. [CrossRef] [PubMed]

44. Ito, M.; Ohmori, I.; Nakahori, T.; Ouchida, M.; Ohtsuka, Y. Mutation screen of GABRA1, GABRB2 and GABRG2 genes in Japanese patients with absence seizures. Neurosci. Lett. 2005, 383, 220-224. [CrossRef]

45. Hernandez, C.C.; Tian, X.; Hu, N.; Shen, W.; Catron, M.A.; Yang, Y.; Chen, J. Dravet syndrome-associated mutations in GABRA1, GABRB2 and GABRG2 define the genetic landscape of defects of GABA(A) receptors. Brain Commun. 2021, 3, fcab033. [CrossRef]

46. Geffrey, A.L.; Pollack, S.F.; Bruno, P.L.; Thiele, E.A. Drug-drug interaction between clobazam and cannabidiol in children with refractory epilepsy. Epilepsia 2015, 56, 1246-1251. [CrossRef]

47. Sills, G.J.; Rogawski, M.A. Mechanisms of action of currently used antiseizure drugs. Neuropharmacology 2020, $168,107966$. [CrossRef]

48. Greenfield, L.J., Jr. Molecular mechanisms of antiseizure drug activity at GABAA receptors. Seizure 2013, 22, 589-600. [CrossRef]

49. Löscher, W.; Potschka, H.; Sisodiya, S.M.; Vezzani, A. Drug Resistance in Epilepsy: Clinical Impact, Potential Mechanisms, and New Innovative Treatment Options. Pharmacol. Rev. 2020, 72, 606-638. [CrossRef]

50. Absalom, N.L.; Liao, V.W.Y.; Kothur, K.; Indurthi, D.C.; Bennetts, B.; Troedson, C.; Mohammad, S.S. Gain-of-function GABRB3 variants identified in vigabatrin-hypersensitive epileptic encephalopathies. Brain Commun. 2020, 2, fcaa162. [CrossRef]

51. Billakota, S.; Devinsky, O.; Kim, K.W. Why we urgently need improved epilepsy therapies for adult patients. Neuropharmacology 2020, 170, 107855. [CrossRef] [PubMed]

52. Kim, J.J.; Gharpure, A.; Teng, J.; Zhuang, Y. Shared structural mechanisms of general anaesthetics and benzodiazepines. Nature 2020, 585, 303-308. [CrossRef] [PubMed] 